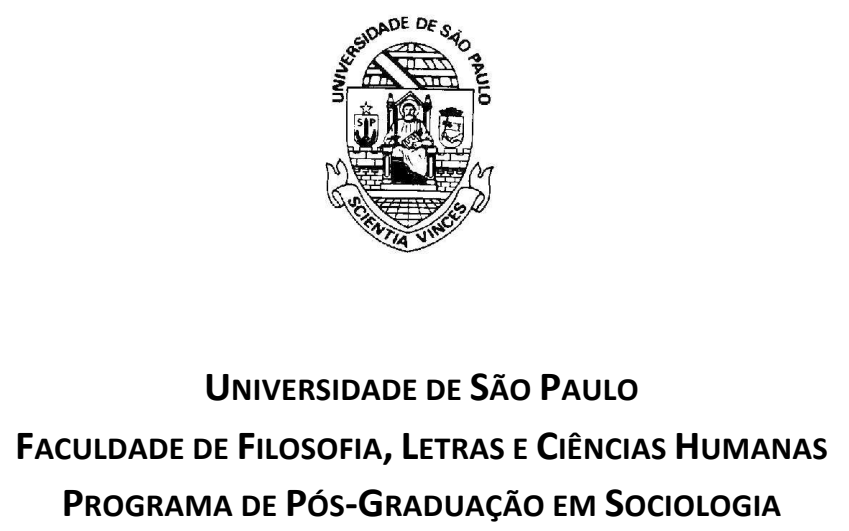

\title{
OS TRABALHADORES SUBCONTRATADOS \\ da Região Metropolitana de São paulo: \\ PRECARIEDADE OU ESTABILIZAÇÃO?
}

Jonas Tomazi Bicev

Dissertação apresentada ao Programa de Pós-Graduação em Sociologia da Faculdade de Filosofia, Letras e Ciências Humanas da Universidade de São Paulo, para obtenção do título de Mestre em Sociologia.

Orientadora: Profa. Dra. Nadya Araujo Guimarães

São Paulo

Julho de 2010 
JONAS TOMAZI BICEV

\section{OS TRABALHADORES SUBCONTRATADOS \\ da Região Metropolitana de São paulo: \\ PRECARIEDADE OU ESTABILIZAÇÃO?}

Dissertação apresentada ao Programa de PósGraduação em Sociologia da Faculdade de Filosofia, Letras e Ciências Humanas da Universidade de São Paulo, para obtenção do título de Mestre em Sociologia.

Área de Concentração: Sociologia do Trabalho.

Orientadora: Profa. Dra. Nadya Araujo Guimarães

São Paulo

Julho de 2010 


\section{DeDicatóRIA}

Aos meus pais, Cássia M. T. T. Bicev e Aparecido Bicev, por sempre acreditarem na minha recuperação e incentivarem meu estudo. 


\section{AgRAdeCIMENTOS}

Agradeço, inicialmente, à Profa. Dra. Nadya Araujo Guimarães, pessoa muito importante para minha formação, por me guiar e orientar durante as rotinas de aulas, pesquisas e estudos. O número de referências e citações expressam a admiração e o respeito que tenho por ela.

Em seguida, agradeço a Paulo Henrique da Silva e Marcus Vinicius Farbelow por terem me introduzido ao trabalho com os bancos de dados e me transmitirem as primeiras técnicas de análises. Sem ajuda deles e a assistência recebida parte dessa dissertação não seria finalizada.

Agradeço aos professores Iram Jacome Rodrigues e Flavia Consoni pelos comentários e sugestões que fizeram quando do meu Exame de Qualificação. A Flávia Consoni cabe registrar meu especial agradecimento por ter acompanhado o meu trabalho desde o início, por haver permitido que eu a acompanhasse em algumas de suas idas a campo e por ter sido sempre uma importante interlocutora.

Da mesma forma, agradeço a Vagner Bessa, parceiro na pesquisa mais ampla que, durante o meu curto mas muito importante período de trabalho no Seade, me ensinou não só a processar os dados da PAEP, como também, a verificá-los e interpretálos criticamente.

Agradeço a Priscila Vieira, pessoa com a qual há mais tempo compartilho minhas dúvidas e rotina de trabalho e que vem se mostrando uma brilhante pesquisadora. Também agradeço a Uvanderson da Silva, colega que sempre acompanhou nosso trabalho e com quem ainda hoje compartilho referências e indicações bibliográficas.

Mesmo os que estão mais longe, não são menos importantes. Assim, Guilherme Xavier Sobrinho também recebe meus agradecimentos; seus textos e capítulos sempre me ajudaram, e suas exposições e intervenções sempre foram agradáveis. Aos colegas mais antigos do Seminário de Orientação também agradeço: Rose Rosendo, Maria Inês, Gisela Tartuce, Maria Carla Carrochano e outros mais de quem talvez eu tenha esquecido.

Aos meus antigos colegas de iniciação cientifica, como Luis Felipe Hirano e Vando da Paz Nascimento, também registro minha gratidão; a divisão de trabalho feita entre nós foi fundamental para que cada um continuasse a sua trajetória de pesquisas. $\mathrm{O}$ 
mesmo vale para os meus atuais companheiros e companheiras de trabalho, como Murillo M. A. de Brito, Monise Picanço, Mariel Deak, Barbara Vazquez, Ivo Torres Costa, João Paulo C. Santoro e, até recentemente, Miranda Zoppi. Agradeço por terem assumido a minha parte no trabalho coletivo e, assim, viabilizado minha dedicação exclusiva ao final da dissertação.

Também sou grato aos atuais colegas do Seminário de Orientação, entre eles, Lucas R. Azambuja, Gustavo Taniguti, Eduardo Bonaldi, André V. Nahoum, Rogério Barbosa, Jaime Santos Júnior, Yumi G. dos Santos, Arthur Bueno, Ana C. Andrada e Carlos Carvalho. Todos contribuíram bastante para o enriquecimento bibliográfico desta dissertação e me ajudaram a compartilhar dúvidas e possíveis caminhos de interpretação.

Agradeço ao CNPq pela bolsa de mestrado que me foi outorgada, através do Programa de Pós-Graduação em Sociologia da Universidade de São Paulo, a cujos professores e funcionários também muito devo.

Por fim, registro a minha divida ao apoio recebido do INCT/Centro de Estudos da Metrópole, em cuja equipe de jovens pesquisadores me integro e a cujo programa de pesquisas este trabalho esteve articulado. Isso me permitiu não apenas o benefício do dialogo intelectual, como o crucial apoio à pesquisa, em especial na forma de acesso ao banco de dados da Rais-Migra, especialmente preparado por este para caracterizar a dinâmica do mercado de trabalho e as trajetórias dos trabalhadores na Região Metropolitana de São Paulo. 


\section{RESUMO}

BICEV, J. T. Os Trabalhadores Subcontratados na Região Metropolitana de São Paulo: estabilidade ou precarização? 2010, 74f. Dissertação (Mestrado) Faculdade de Filosofia, Letras e Ciências Humanas, Universidade de São Paulo, São Paulo, 2010.

O recente aumento da subcontratação formal de trabalho tem estimulado um importante debate sobre a qualidade da inserção e do vínculo estabelecido entre os trabalhadores e as empresas de intermediação de mão-de-obra. Visando contribuir para esse debate, a presente dissertação organiza-se de modo a alcançar três objetivos: em primeiro lugar, caracterizar a natureza e as transformações recentes no mercado de trabalho brasileiro; em segundo lugar, analisar o crescimento recente dos intermediários privados do mercado de trabalho; em terceiro lugar, investigar, com base em dados transversais e longitudinais da RAIS para a região metropolitana de São Paulo no período compreendido entre 1998 e 2007, se a passagem pelo emprego temporário ou terceirizado constitui-se num meio de acesso a empregos capazes de garantir a permanência no mercado formal ou se, pelo contrário, insere os indivíduos numa seqüência de empregos marcados pela fragilidade ou instabilidade dos vínculos.

Palavras-chave: Mercado de Trabalho. Subcontratação. Intermediação. Agencias de emprego. São Paulo. Brasil.

\section{ABSTRACT}

The increasing relevance of labor outsourcing has improved and deepened the debate on the quality of job opportunities provided by labor market intermediaries and their relationship with the job seekers in different parts of the world. This dissertation aims at contributing to this debate and has three main goals: first, reflect on the structure and recent transformations in the Brazilian labor market; second, analyze the growth and changing importance of private intermediaries in this market; third, scrutinize crosssectional and longitudinal data provided by the Brazilian Ministry of Labor (RAIS data basis) on the dynamics of formal jobs in São Paulo Metropolitan Region, during 1998 and 2007, in order to investigate if the access to temporary and/or outsourced jobs can provide the workers with a carrier in the formal labor market or instead only allows them to engage in a sequence of fragile and unstable employment contracts.

Key words: Labor market. Outsourcing. Intermediaries. Employment agencies. São Paulo. Brazil. 


\section{LISTA DE TABELAS}

\section{Capítulo II}

TABELA II. 1: Percursos típicos dos que estiveram ocupados nas empresas de locação, agenciamento e seleção (Região Metropolitana de São Paulo: painel prospectivo dos ocupados em 1996, acompanhados até 2002).

\section{CAPítulo III}

TABELA III. 1: Sexo dos trabalhadores ocupados nas empresas de seleção, agenciamento e locação de mão-de-obra, em 1998

TABELA III. 2: Distribuição etária dos trabalhadores ocupados nas empresas de seleção,agenciamento e locação de mão-de-obra, em 1998.

TABELA III. 3: Escolaridade dos trabalhadores ocupados nas empresas de seleção,

TABELA III. 4: Tipo de admissão dos trabalhadores ocupados nas empresas de seleção, agenciamento e locação de mão-de-obra, em 1998.

TABELA III. 5: Tipo de vínculo dos trabalhadores ocupados nas empresas de seleção, agenciamento e locação de mão-de-obra, em 1998.

TABELA III. 6: Faixa salarial dos trabalhadores ocupados nas empresas de seleção, agenciamento e locação de mão-de-obra, em 1998.

TABELA III. 7: Vínculos subseqüentes dos temporários ( $N=119.522)$ que em 1998 estavam ocupados nos serviços de seleção, agenciamento e locação de mão-de-obra.

TABELA III. 8: Percurso dos temporários que em 1998 estavam ocupados nos serviços de seleção, agenciamento e locação de mão-de-obra.

TABELA III. 9: Distribuição dos empregados das agências em 1998, segundo as ocupações. 53

TABELA III. 10: Percurso dos terceirizados ( $\mathrm{N}=46.632)$ que em 1998 estavam ocupados nos serviços de seleção, agenciamento e locação de mão-de-obra.

TABELA III. 11: De onde provêm os trabalhadores das empresas de locação, agenciamento e seleção?(RMSP: painel retrospectivo dos ocupados em 2007 acompanhados desde 2000).....54

TABELA III. 12: Tipo de admissão dos trabalhadores ocupados nas empresas de seleção, agenciamento e locação de mão-de-obra (RMSP: painel retrospectivo dos ocupados em 2007 acompanhados desde 2000)

TABELA III. 13: Vínculo de trabalho anterior à passagem pelo setor de seleção, agenciamento e locação de mão-de-obra (RMSP: painel retrospectivo dos ocupados em 2007 acompanhados desde 2000)

TABELA III. 14: Percurso dos temporários que em 1998 foram contratados diretamente pelas indústrias de transformação.

TABELA III. 15: Vínculos subseqüentes dos temporários que em 1998 foram contratados diretamente pelas indústrias de transformação.

TABELA III. 16: Percurso dos trabalhadores que em 1998 estavam ocupados nos serviços prestados principalmente às empresas $(\mathrm{N}=191.545)$. 
TABELA III. 17: Tipos de vínculos dos trabalhadores que em 1998 estavam ocupados nos serviços prestados principalmente às empresas.

TABELA III. 18: Tipos de vínculos dos trabalhadores que em 1998 estavam ocupados nos serviços de limpeza e higienização $(\mathrm{N}=172.273)$.

TABELA III. 19: Percurso dos trabalhadores que em 1998 estavam ocupados nos serviços de limpeza e higienização.

TABELA III. 20: Percurso dos trabalhadores que em 1998 estavam ocupados nas atividades de investigação, vigilância e segurança $(\mathrm{N}=81552)$.

TABELA III. 21: Número médio da quantidade de admissões, desligamentos e ocupações exercidas entre 1998 e 2007

TABELA III. 22: Distribuição sexual dos trabalhadores ocupados nos serviços auxiliares em 1998.

TABELA III. 23: Tipo de vínculo dos trabalhadores que em 1998 estavam ocupados nas atividades de investigação, vigilância e segurança.

TABELA III. 24: Média dos salários nos dois extremos do percurso profissional, 1998 e 2007.61

TABELA III. 25: Distribuição relativa dos empregados das agências em 2007, segundo as ocupações. 


\section{OS TRABALHADORES SUBCONTRADOS \\ DA REgIÃo METROPOLITANA dE SÃo PAULO: ESTABILIDADE OU PRECARIZAÇÃo?}

Jonas Tomazi Bicev

\section{SUMÁRIO}

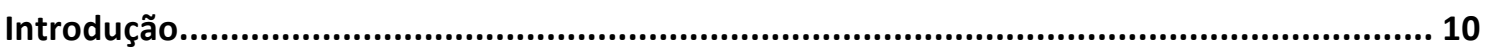

Capítulo I - As dimensões estruturais e conjunturais da flexibilização do trabalho ............... 13

I.I - A formação do mercado de trabalho urbano-industrial brasileiro e o histórico de sua flexibilidade

II.II - O Brasil a partir dos anos 1990: desemprego, novas formas contratuais e a recuperação econômica.......

Capítulo II - A subcontratação de mão-de-obra e as agências privadas de trabalho

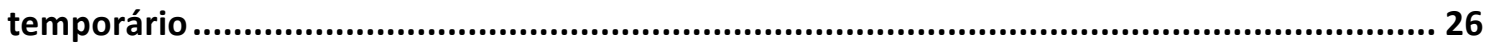

II.I - As agências privadas de trabalho temporário no Brasil .................................................... 32

II.II- As agências e o desempenho de quem acessa seus serviços ...........................................36

Capítulo III - Os trabalhadores intermediados na Região Metropolitana de São Paulo......... 47

III.I - O perfil dos empregados nas empresas de seleção, agenciamento e locação de mão-deobra.

III.II - As trajetórias de trabalho dos empregados nas empresas de seleção, agenciamento e

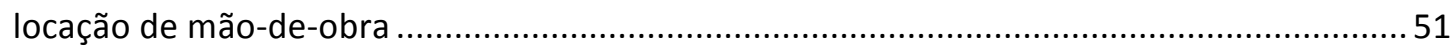

III.III - Os empregados das agências vis-à-vis os trabalhadores dos serviços auxiliares...........57

Conclusão: $O$ emprego intermediado por agências: forma de precarização ou mecanismo

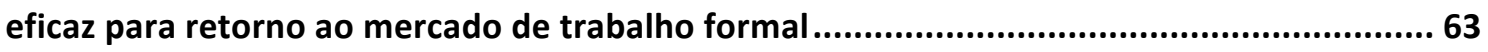

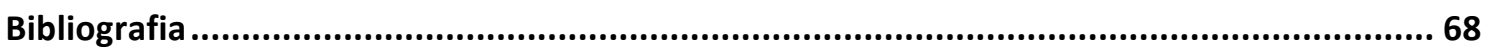




\section{INTRODUÇÃO}

Nas últimas duas décadas, fenômenos como a informalidade, o desemprego e o crescimento do emprego subcontratado tem alterado a configuração do mercado de trabalho de importantes metrópoles brasileiras.

Resultantes do aumento da concorrência internacional, das inovações tecnológicas e dos ajustes na gestão das organizações, a persistência e a difícil reversão de tais tendências, mesmo em períodos de recuperação do crescimento econômico, colocaram em questão diversos pressupostos quanto a sua transitoriedade. Assim, o rápido e contínuo crescimento da subcontratação formal de mão-de-obra, num ritmo muito mais célere do que o ritmo da recente redução do desemprego e da informalidade, indicava que atualmente essa prática já havia sido incorporada pelas estratégias empresariais dos mais variados setores da economia, sendo muito mais do que uma estratégia de defesa, típica de atividades intensivas em mão-de-obra.

Um importante ator nesse processo foram os intermediários privados do mercado de trabalho - popularmente conhecidos como agências de emprego e suas variantes - muitos, além de recrutar, selecionavam e assumiam a condição de empregadores formais da mão-de-obra que agenciavam. Assim, Pochmann (2007) verificou que, entre 1985 e 2005, só no Estado de São Paulo, o número de trabalhadores formais em empresas de intermediação foi multiplicado por sete vezes, passando de 60,5 mil para quase 424 mil empregados (RAIS/MTE e Guias de contribuição sindical do SINDEEPRES apud. Pochmann, 2007). Segundo Guimarães e Souza (2007), somente entre os anos de 1994 e 2005, esse número quase quadruplicou (RAIS/MTE apud. Guimarães e Souza, 2007).

Esses resultados, a princípio, contra-intuitivos, reforçavam meus achados anteriores (Bicev, 2007) ${ }^{1}$ e, além disso, estimulavam meu interesse em investigar o efeito da passagem pelo emprego temporário ou terceirizado na trajetória profissional dos indivíduos. Em termos mais específicos, a partir deles, decidi investigar se o emprego temporário ou terceirizado facilitava o acesso a empregos capazes de garantir a

\footnotetext{
${ }^{1}$ No ano de 2007, em relatório final de iniciação cientifica, verifiquei que ao longo de toda década de 1990, cerca de $80 \%$ dos subcontratados da Região Metropolitana de São Paulo portavam carteira assinada (Pesquisa de Emprego e Desemprego, PED/SEAD, 1988-2004, apud. Bicev, 2007).
} 
permanência no mercado formal, ou se, pelo contrário, inseria os indivíduos numa seqüência de empregos marcados pela fragilidade ou instabilidade dos vínculos.

No Brasil tal proposta mostrou-se viável pelo acesso às informações contidas no Relatório Anual de Informações Sociais, disponibilizadas em forma de micro-dados pelo Ministério do Trabalho e do Emprego ${ }^{2}$. Dentre suas diversas modalidades optou-se pela utilização tanto de sua modalidade transversal, quando - e em especial - da sua modalidade longitudinal, a Migra (RAIS-Migra), pela vantagem de ser organizada em forma de painel e permitir estudos de mudanças no tempo dos destinos ocupacionais da mão-de-obra empregada no interior do mercado de trabalho formal ${ }^{3}$.

Entretanto, sem identificar a natureza e as características específicas do mercado de trabalho nacional, a compreensão do crescimento da subcontratação formal na Região Metropolitana de São Paulo ficaria muito incompleta. Por isso, procuro, no primeiro capítulo, recuperar brevemente a história do desenvolvimento do mercado de trabalho urbano-industrial brasileiro para enfatizar como a flexibilidade do trabalho adquire diferentes dimensões, ao longo da história do processo de acumulação capitalista.

Esse capítulo assenta as bases teóricas da discussão e, além disso, prepara o terreno para se responder outro desafio, ou seja, explicar porque os intermediários privados crescem mesmo em mercados com elevada margem de negociação entre empresas e trabalhadores. Assim, a sistematização da literatura sobre o surgimento e o desenvolvimento das empresas de intermediação de mão-de-obra, foi toda realizada com o intuito de explicar sua demanda em diferentes realidades e a freqüência de seu uso em distintas áreas, restritas ou específicas, da produção.

Realizado, esses objetivos, no terceiro capítulo, chego à análise empírica prometida, na qual, em primeiro lugar, analiso o perfil dos trabalhadores ocupados por meio dos intermediadores de mão-de-obra para, em seguida, observar longitudinalmente a coorte dos trabalhadores que em 1998 se inseriram ou retornaram ao mercado formal por meio das empresas de seleção, agenciamento e locação, de modo a identificar seu

\footnotetext{
${ }^{2}$ Agradeço ao Centro de Estudos da Metrópole, para quem os dados foram inicialmente produzidos, pela disponibilização dos mesmos para meu uso.

${ }^{3}$ Constituindo-se num registro administrativo destinado principalmente ao controle da arrecadação e concessão de benefícios pelo Ministério da Previdência Social, seu acesso nos fornece informações sobre o perfil (faixa etária, grau de instrução, gênero, ocupação e etc.) e sobre o tipo de vínculo da mão-de-obra empregada; todos esses dados disponibilizam-se desagregados por tamanho dos estabelecimentos, pelo setor de atividade econômica, pela natureza jurídica do empreendimento e pela localização geográfica.
} 
perfil e seu percurso ocupacional até 2007. Essa análise se completa com a comparação dos percursos de outras quatro coortes de trabalhadores comumente empregados nos serviços auxiliares - ou seja, a dos temporários contratados diretamente pela indústria, dos trabalhadores dos serviços prestados principalmente às empresas, dos trabalhadores da limpeza e da vigilância - cujo alvo é ressaltar as características específicas das agências quanto ao tipo de inserção e dos vínculos estabelecidos por seus trabalhadores.

Por fim, encerro a dissertação com o capítulo de conclusão no qual sistematizo e articulo os principais achados dos capítulos anteriores. 


\section{CAPÍtulo I}

\section{As Dimensões Estruturais e Conjunturais da Flexibilização do Trabalho.}

A flexibilidade do trabalho é um fenômeno complexo e multifacetado. Gautié (2006) bem sistematiza a recente discussão em torno do tema, desvelando que ela pode ser organizada ao longo de quatro dimensões:

“A flexibilidade numérica (ou quantitativa) externa - que se refere à facilidade de contratar e demitir para ajustar o volume de trabalho à produção; a flexibilidade numérica interna - que abrange a possibilidade de ajustar a carga de trabalho, as horas de trabalho, ao invés do número de trabalhadores; a flexibilidade funcional (ou qualitativa) - que explora o potencial de organização do trabalho, tais como polivalência e rotação de tarefas - e, finalmente, a flexibilidade salarial - devida à sensibilidade dos salários às conjunturas econômicas” (Gautié, 2006, p.14).

Nesse capítulo concentro minha discussão nas dimensões salarial e numérica externa (ou quantitativa) assumidas pela flexibilidade do trabalho na estrutura produtiva brasileira. Para tal, recupero brevemente a história do desenvolvimento do mercado de trabalho urbano-industrial brasileiro para enfatizar como ambas as dimensões da flexibilidade foram produzidas, entre nós, a partir de uma estrutura legal talhada na história do processo de acumulação capitalista, combinada com a recente intensificação da concorrência promovida pela abertura dos mercados.

Entendo que é sobre o pano de fundo da ocorrência deste fenômeno que se pode bem introduzir a discussão sobre a crescente importância assumida pelos intermediários privados na operação do mercado de trabalho. No Brasil num tal contexto de reconfiguração e reorganização dos modelos produtivos, investigarei, ao longo desta dissertação, se tais atores são capazes de minimizar os efeitos do desemprego duradouro ou recorrente; ou se, pelo contrário, contribuem ativamente para as transições e a instabilidade nas trajetórias dos trabalhadores. 


\section{I.I - A formação do mercado de trabalho urbano-industrial brasileiro e o histórico de sua flexibilidade.}

O célere aumento das modalidades formais e informais de subcontratação do trabalho e a crescente participação dos terceirizados e temporários no total dos empregos formais gerados a partir dos anos 1990 são fenômenos que refletem as novas configurações assumidas pela flexibilidade no interior do processo produtivo.

Digo que se trata de uma "nova flexibilidade" porque a literatura sobre o contexto de emergência do desenvolvimento industrial brasileiro e sobre as condições institucionais de sua expansão de há muito já sugeria que a regulação de nosso mercado de trabalho oferecia uma ampla margem para a negociação entre empregadores e empregados. Assim, pressupondo que as práticas organizacionais refletem em boa medida as disputas internas e o quadro regulatório no qual estão inseridas, torna-se pertinente analisar mais detidamente as especificidades assumidas pela regulação e as características gerais do mercado de trabalho em algumas das principais etapas do desenvolvimento urbano-industrial brasileiro ${ }^{4}$.

Segundo Oliveira (1972), o sucesso inicial de nossa industrialização dependeu, basicamente, da capacidade do Estado viabilizar a exploração da oferta elástica de mãode-obra, terras e recursos naturais. Desse modo, dado o contexto de crise do comércio internacional $^{5}$ e ausência de magnitudes prévias de acumulação capitalista, o reconhecimento formal das reivindicações trabalhistas na CLT (Consolidação das Leis Trabalhistas ) e a introdução da lei do salário mínimo, já em 1943, antes de atenderem às necessidades da população, tinham o objetivo de atrair a mão-de-obra aos grandes centros urbanos e nivelar por baixo os salários dos trabalhadores industriais (Oliveira, 2003, p.40).

Ou seja, ao oferecer salários superiores à maioria dos rendimentos auferidos pelo trabalho no campo e ao suprimir a "livre" barganha, o Estado garantia a criação de um "exército de reserva", ao mesmo tempo em que limitava os aumentos dados à mão-deobra qualificada, compensando no agregado, os ganhos de uns pelas perdas de outros ${ }^{6}$.

\footnotetext{
${ }^{4}$ Tomados, aqui, a partir da Revolução de 1930, momento que segundo Oliveira (2003): "marca o fim de um ciclo e o início de outro na economia brasileira: o fim da hegemonia agrário-exportadora e o início da predominância da estrutura produtiva de base urbano-industrial" (Oliveira, 2003, p. 35).

${ }^{5}$ Decorrente da preparação para a Segunda Guerra Mundial (1939-1945).

${ }^{6}$ Com efeito a indústria, dentre outras atividades urbanas, paga salários mais altos que os rendimentos auferidos no campo em razão da sua maior produtividade e valor agregado das atividades urbanas.
} 
A agricultura, por sua vez, apesar de enfraquecida politicamente, dividia-se em dois setores: um voltado à exportação, responsável pela geração de divisas, e outro baseado na ocupação muitas vezes irregular de terras férteis e pouco exploradas, as quais, junto com a informalidade, garantiam alimentos e serviços baratos à população urbana (Oliveira, 2003, pp. 38- 39).

Embora sempre existissem contestações e conflitos de classes, tais conflitos eram pontuais e tinham pouca repercussão uma vez que o Estado logo reprimiu os elementos mais radicais dos movimentos e criou mecanismos institucionais que trouxeram as lideranças dos maiores sindicatos urbanos para o interior de seu aparelho burocrático. Segundo Boito Jr (1991), além de induzir a uma postura conciliatória, a unicidade sindical (reconhecimento de um sindicato por categoria em cada município) $e$ as contribuições obrigatórias por força de lei, então instituídas, tornaram dependentes do reconhecimento estatal tanto o financiamento quanto o poder dos sindicatos para constranger os capitalistas (Boito Jr., 1991, p.27) ${ }^{7}$.

Isso tudo afastava o mercado de trabalho da concorrência perfeita, sem, no entanto, (como adiante ficará ainda mais claro) implicar uma excessiva rigidez. Na verdade, não seria incorreto afirmar que as reformas trabalhistas do período Vargas visavam afastar os elementos competitivos que poderiam ameaçar o início de nosso desenvolvimento industrial (em especial a elevação excessiva dos salários num contexto de demanda por mão-de-obra especializada), de modo que até mesmo a agricultura tradicional e os serviços urbanos informais, tornavam-se partes fundamentais e funcionais para a reprodução da nossa dinâmica de acumulação.

Diferentemente do que aconteceu na Europa e nos EUA - onde as transformações tecnológicas desenvolveram-se ao longo de anos, geralmente

\footnotetext{
Entretanto, na época, essa diferença não chegava a ser excessiva, dado que o horizonte médio para o cálculo econômico dos salários era oferecido pelo salário mínimo, definido pelas entidades de classes patronais e trabalhistas subordinadas aos interesses do Governo. Cito "se fosse verdade que os niveis do salário mínimo estivessem por cima de níveis de pura barganha num mercado livre (...) o sistema entraria em crise pela impossibilidade de acumular; o que se viu após a implementação da legislação trabalhista foi exatamente o contrário: é a partir dai que um tremendo impulso é transmitido à acumulação, caracterizando toda uma nova etapa de crescimento da economia brasileira" (Oliveira, 2003, p.39).

${ }^{7}$ Isso não nos deve levar a crer, entretanto, que os sindicatos tenham se tornado estruturas totalmente isentas das pressões oriundas da base, inclusive o próprio Estado. Há uma corrente da literatura que procura enfatizar, ademais, as contrapartidas oferecidas na CLT aos trabalhadores. A principal ênfase recai sobre o reconhecimento formal dos Institutos de Aposentadorias e Pensões (IAPs), fundos financeiros formados pelas contribuições dos trabalhadores, que mais tarde serão o germe dos programas sociais de moradia, saneamento básico, saúde e etc. (Santos,1979).
} 
antecedidas por uma elevação do custo do trabalho - por aqui, a incorporação de tecnologia importada se deu de modo rápido e acelerado, eliminando postos de trabalho sem que os trabalhadores fossem suficientemente organizados para poderem elevar os rendimentos médios auferidos na indústria (Oliveira, 203, p.67).

Desse modo, a chegada das empresas estrangeiras, a introdução dos ramos dinâmicos e os investimentos maciços em infra-estrutura ocorridos no período Kubistchek (1956-1961), ao invés de conterem a deterioração salarial, acabaram por agravá-la, uma vez que o custo de vida tornava-se mais elevado com a expansão da infra-estrutura urbana ${ }^{8}$. De acordo, com pesquisa do DIEESE, publicada em 1969, num período de onze anos (1958-1969), tanto o salário real do chefe de família-tipo, quanto a renda familiar tinham se reduzido em 39,3\% e 10\%, respectivamente. Em termos concretos, isso significa que o tempo de trabalho necessário para garantir a reprodução tinha se elevado e mais membros das famílias eram obrigados a procurar uma fonte de renda no mercado de trabalho (Pesquisa sobre o padrão de vida da classe trabalhadora da cidade de São Paulo, 1969; apud. Oliveira, 2003, p.88).

Ou seja, embora desfrutassem de maior acesso ao consumo de bens duráveis (como eletrodomésticos) $)^{9}$, as necessidades básicas da população urbana - como transportes, água, luz, alimentação, telefone - encareciam-se por não comportarem mais soluções primitivas ou autônomas. Assim, à medida que o salário se tornava insuficiente, a rotatividade e a fragilidade dos vínculos tornavam-se características crônicas de nosso mercado de trabalho, e foram, em 1966, institucionalizadas pelo Regime Militar (1964-1985) com a introdução do Fundo de Garantia por Tempo de Serviço (FGTS) (Rivero, 2009, pp. 106, 109, 111-115).

Com sua criação, a estabilidade legal dos trabalhadores com mais de dez anos de firma foi substituída pelo direito de receber, em caso de demissão sem justa causa, um

\footnotetext{
${ }^{8}$ A parceria com o capital internacional foi a saída encontrada pelo governo da época (anos 1950) para remediar nossa carência de acumulação e bens de capital (máquinas e equipamentos). Contudo, o contexto internacional não era um dos mais favoráveis à industrialização brasileira. Os EUA se preocupavam com a reconstrução européia e ainda nos enxergavam como exportadores de bens primários (as empresas líderes norte-americanas como a General Motors e a Ford só produziram automóveis de passeio em território nacional depois de 1964). Os financiamentos feitos de governo a governo praticamente inexistiram e o governo nacional, além de atrair empresas que buscavam se recuperar no mercado mundial (Ex.: Volkswagen, Toyota, Simca, Mercedes-Bens), teve de recorrer ao endividamento privado, de prazos curtos (Oliveira, 2003, pp. 72-76).

9 Justamente em virtude da elevação do número de habitantes nos estratos mais baixos e dos ganhos de renda real dos membros dos estratos mais altos, os quais elevaram a massa total de renda na economia como um todo e em cada um dos estratos.
} 
fundo de capitalização ${ }^{10}$, uma multa de $40 \%$ sobre esse mesmo fundo e o aviso prévio (direito de trabalhar duas horas menos, remuneradas, para a procura de um novo emprego). Apesar de reconhecer uma prática já existente e tentar estender a proteção, na ausência de garantias de empregos e salários, tais concessões acabaram por incentivar acordos nos quais os trabalhadores abriam mão de parte dos seus direitos. Segundo estimativas oficiais, em 1995, mais de $80 \%$ das ações trabalhistas se resolviam sem sequer chegarem a julgamento. Ademais, enquanto uma audiência de conciliação durava em média 47 dias, o tempo médio para uma nova decisão aumentava para 15 meses, chegando até ao tempo médio de quatro anos caso a ação percorresse todas as cadeias hierárquicas do judiciário nacional (Camargo, 1996, p.20; Carelli, 2007, p. 61).

Portanto, essa lentidão da justiça do trabalho, somada ao custo de abertura e manutenção das ações, ao baixo custo de dispensa, ao baixo retorno direto dos impostos, e à possibilidade de acessar o fundo de garantia em caso de demissão, tudo isso deixava nossa regulação distante da rigidez. Ou seja, nosso mercado de trabalho era suficientemente flexível para que, num contexto de crescimento econômico, tanto empregadores quanto trabalhadores negociassem o rompimento dos vínculos de acordo com seus interesses (Camargo 1996, p. 20-22).

Entretanto, após quarenta anos de industrialização, a concentração resultante no final da década de 1970, impôs limites ao próprio desenvolvimento. Os ramos têxteis, de vestuário, calçados, alimentação e outras indústrias voltadas às necessidades básicas sofriam de uma crise de realização, decorrentes da deterioração dos salários reais; já a produção interna dos bens de capital era prejudicada à medida que o impulso das indústrias de bens de consumo duráveis - que se sustentava num mercado consumidor estreito, mas grande em termos de renda (classe média) - apoiava-se na importação de sua tecnologia e maquinário (Oliveira, 2003, p.87; p.103; pp.114-115) ${ }^{11}$.

Sob o impacto de dois choques econômicos externos, decorrentes da súbita elevação do preço do petróleo (promovida pelos principais países exportadores reunidos na OPEP) em 1973 e 1979, e logo que a estagnação tornou-se evidente, o Regime Militar se enfraqueceu e uma onda de greves e paralisações se difundiu das indústrias do

\footnotetext{
${ }^{10}$ Correspondente a $8 \%$ do salário de cada mês empregado.

11 Cabe lembrar que os anos de 1962/1967 foram marcados por uma recessão que prejudicou os investimentos e a indústria de bens de capital nacional. Assim, o recurso às importações foi novamente uma condição necessária para a continuidade do crescimento.
} 
grande $\mathrm{ABC}^{12}$ para todo o Estado de São Paulo, propagando-se, em seguida, para outros pólos de concentração industrial do Brasil. Distintas quanto ao grau de espontaneísmo e capacidade de resistência dos movimentos, as campanhas salariais de 1978, 1979 e 1980, foram nítidas reações, impulsionadas principalmente pelos sindicatos dos metalúrgicos, aos índices oficiais de inflação e a política de arrocho salarial (Maroni, 1982; Antunes, 1988; Abramo, 1999; Rodrigues, 1999) ${ }^{13}$.

Embora o movimento tenha conquistado relativo sucesso político, o mesmo não se pode dizer em relação aos efeitos salariais imediatos, os quais foram contidos em razão do recrudescimento do regime e do contexto economicamente recessivo intensificado com a "crise da dívida" dos anos 1980. Esse período de insegurança e de recessão mundial marcou o fim da trajetória de desenvolvimento econômico ascendente em quase toda a América Latina, uma vez que a elevação dos juros para a concessão de créditos e novos empréstimos culminou na interrupção, por quase dez anos, do fluxo de financiamento externo aos países da região ${ }^{14}$.

O caso brasileiro foi um exemplo concreto desse processo e, dada a dimensão exagerada de sua dívida externa, foram derrotadas todas as tentativas de ajustamento levadas a cabo pelo Executivo durante a década de 1980. Pressionado pelos credores internacionais a reduzir o déficit público, a aumentar as exportações e a reduzir as importações, na medida em que isso envolvia, de um lado, a redução do investimento público (através do investimento direto do Estado ou do subsídio aos investimentos

\footnotetext{
${ }^{12}$ Formadas pelos municípios de Diadema, Mauá, Ribeirão Pires, Rio Grande da Serra, Santo André, São Bernardo do Campo e São Caetano do Sul, a região foi o berço da indústria moderna no Brasil a partir da instalação das indústrias automobilísticas na década de 1950.

${ }^{13}$ Segundo Abramo (1999) a defasagem entre os índices de crescimento da indústria e a evolução dos salários foi ampliada a partir das modificações introduzidas na política salarial em 1964 pelo regime ditatorial recém-instalado. De 1964 a 1968, as taxas de reajuste salarial foram fixadas sistematicamente abaixo do aumento do custo de vida, acarretando uma queda de $23 \%$ no salário real da categoria. Embora entre 1969 a 1973 houvesse uma significativa melhoria da ordem de 6\%, esta esteve aquém do necessário para repor as perdas do período anterior e compensar o aumento de produtividade do setor. Entre 1973 e 1974 houve uma nova e acentuada redução do salário real que nem os reajustes de 10\% entre 1975 e 1976 pôde (re) estabelecer os níveis de remuneração de 1973 (Abramo, 1999, 59).

14 Segundo Kutner (1998) a crise da dívida dos países latino-americanos passa pelo processo de desregulamentação bancária levada a cabo pelo governo norte-americano e britânico na segunda metade da década de 1970. Para o autor a partir das reformas bancárias, os bancos passaram a oferecer créditos para os empreendimentos ou governos dispostos a pagar os maiores juros. Assim: "Empréstimos a juros altos, feitos a frágeis regimes do Terceiro Mundo, viraram moda no fim dos anos 70 e início dos anos 80. Tanto banqueiros como seus fiscais convenceram-se de que governos não podem falir. Os governos beneficiários dos empréstimos, por seu lado, seguiram o dito segundo o qual basta se endividar bastante com um banqueiro para ganhar um sócio, e adquiriram mais empréstimos para pagar os juros dos antigos" (Kutner, 1998, p. 49). Sistema que chegou à falência com a moratória do México de 1982.
} 
privados) e, de outro, desvalorizações reais das moedas locais, a principal conseqüência foi a aceleração da inflação (Bresser-Pereira, 1990; Fernandes e Pais, 1991).

Segundo Bresser-Pereira (1990), a partir de fevereiro de 1990 o governo perdia o controle sobre a inflação que historicamente caracterizava a economia brasileira. Ou seja, até 1989 apesar de elevada (30\% ao mês), a taxa de inflação não crescia de forma explosiva nem sofria fortes flutuações, pelo que os preços continuavam a ser parcialmente indexados de acordo com a inflação passada e continuavam a ser reajustados de forma defasada (não sincrônica). Dito de outro modo, apesar das demandas de reposição salarial, os agentes econômicos ainda aceitavam corrigir sua participação na renda levando em conta apenas as perdas passadas.

Entretanto, após a euforia da redemocratização (1985) e do fracasso do plano cruzado (1986), o conflito distributivo se acirra e o governo não consegue mais evitar os aumentos salariais e seu repasse aos preços ${ }^{15}$. Assim, de acordo com Nakano (1989), desenvolveu-se uma relação "perversa" entre os grandes sindicatos e as grandes empresas monopolistas brasileiras. "Elas formaram uma espécie de pacto defensivo: aceitam sem muita discussão as demandas dos trabalhadores e em seguida as repassam rapidamente para os preços, graças à sua organização em forma de cartel e ao caráter fechado [que na época caracterizava] a economia brasileira" (Nakano, 1989; apud. Bresser-Pereira, 1990, p. 21).

Estava configurada, assim, aquilo que se conhecia como hiperinflação, quando a partir de um desequilíbrio real de preços e salários (real porque os trabalhadores não estavam minimamente satisfeitos com sua participação média na renda), os agentes econômicos formam expectativa firmes de que a inflação está se acelerando e, desta forma, reajustam seus preços de acordo com uma previsão de inflação cada vez mais alta. Nesse momento, o conflito distributivo torna-se tão insustentável que os potenciais efeitos positivos da inflação para o crescimento econômico são interrompidos já que os

\footnotetext{
${ }^{15}$ De fato, segundo Fernandes \& Pais (1991), novamente os principais custos dos ajustes recaíram sobre os salários dos trabalhadores. No contexto da segunda crise do petróleo (1979) e da recessão norteamericana entre os anos 1979/82, os países latino-americanos tiveram dificuldades de manter o superávit necessário ao abatimento da dívida. Desprovidos de novos empréstimos e com as moedas locais desvalorizadas, os salários reais e a renda per capita nos países da América Latina caíram cerca de 10\% entre os anos de 1981 e 1984.
} 
trabalhadores passam a reivindicar, além da reposição, a incorporação nos salários da inflação futura ${ }^{16}$.

Mas, se após a redemocratização a palavra de ordem dos movimentos trabalhistas era a recuperação dos salários, a partir da década de 1990 as novas tentativas de ajustes vão dar origem a novas demandas e uma nova preocupação surge no horizonte dos trabalhadores: o desemprego. Em termos da discussão que aqui nos interessa sobre as reconfigurações da flexibilidade, inicia-se um período no qual $a$ flexibilidade salarial (ou seja, à sensibilidade dos salários às conjunturas econômicas) tornava-se incapaz de conter os efeitos da flexibilidade numérica externa (que se refere à facilidade de contratar e demitir para ajustar o volume de trabalho à produção).

As reformas liberais que se seguiram terão efeitos sobre a organização das empresas e sobre a nova configuração do mercado de trabalho dos anos 1990, de que tratarei no item seguinte.

\section{I.II - O Brasil a partir dos anos 1990: desemprego, novas formas contratuais e a recuperação econômica.}

Após a redemocratização e um período de intensa participação política popular que definiu os contornos da Constituição de 1988, a sociedade brasileira inicia a década de 1990 em meio a inúmeros desafios econômicos. Entre eles se destacam: o peso insustentável de sua dívida externa, o imobilismo gerado por uma excessiva proteção à indústria nacional, o fracasso dos programas de estabilização no combate à inflação e o esgotamento de um modelo de desenvolvimento baseado fundamentalmente na intervenção estatal.

Desse modo, segundo Sallum Jr.(2000), tem início, então, uma série de políticas de liberalização comercial, privatizações e programas de estabilização, que gradualmente vão substituir a estratégia de construção de um sistema industrial nacionalmente integrado pela estratégia de transformar o parque industrial doméstico numa parte do sistema produtivo global. Ou seja, de antigo indutor, o Estado vai reduzindo sua ação ao controle da inflação e deixa o mercado encarregar-se de preservar

\footnotetext{
${ }^{16}$ Entra em colapso assim o ajuste entre os ganhos das empresas e a geração de empregos, ou seja, o mecanismo baseado na elevação mensal dos preços das mercadorias contraposto à elevação anual dos salários (Friedman, 1968; Kuttner, pp.59-60, 1998).
} 
apenas os ramos industriais capazes de competir abertamente numa economia internacionalizada (Sallum Jr., 2000, p. 141).

Embora, depois de quase vinte anos, seja possível verificar os efeitos positivos da modernização, os ajustes promovidos durante os governos Collor/Itamar (19891993), FHC (1994-2002) e no início do governo Lula (2003) modificaram profundamente o modo de absorção das crises econômicas e as características do mercado de trabalho urbano-industrial. Camargo (1996) a partir dos dados da Pesquisa Nacional de Amostra por Domicílios (PNAD -IBGE), constatou que durante toda a década de 80 o desemprego variou entre $4,13 \%$ e 7,55\%. Ademais, a porcentagem de trabalhadores desempregados por mais de 12 meses nunca ultrapassou 18\%, sendo 17,5\% em 1990. A estabilidade relativa dessas taxas, mesmo em momentos de dificuldades econômicas, denotava a natureza da flexibilidade do mercado de trabalho. Assim, se por quase três décadas (entre os anos 1970 e 1990), nosso mercado de trabalho tinha sido flexível sem ser necessariamente inseguro (Camargo, 1996, p. 2830), a partir da década de 90:

"Eleva-se de maneira significativa o tempo de procura de trabalho e a taxa de desemprego total ultrapassa os dois dígitos, sustentando-se em níveis que, nos momentos mais críticos, chegam a alcançar 20\% da população em atividade [na região metropolitana de São Paulo]” (Guimarães, 2009b, p. 48).

Isso significa que a perda do emprego afastava-se da conquista de outro, e o movimento entre ocupação e desemprego era tão regular quanto a entrada e a saída da atividade econômica (atividade e inatividade). Ademais, a inatividade também se torna recorrente e deixava de ser uma condição associada aos extremos da trajetória ocupacional, em precisos momentos do ciclo de vida do trabalhador, ou seja, quando jovens, num momento inicial de entrada no mercado de trabalho, e quando idosos, no momento em que deixam de trabalhar (Guimarães, 2009b, p. 29).

O Plano Real (lançado em 01/07/1994), embora tivesse contido as perdas salariais, intensificou a insegurança dos trabalhadores. Assim, desde que a estabilização assentada na apreciação cambial, nos juros altos e na redução das tarifas de importação pôs fim à flexibilidade dos salários e às correções de preços (recorrentes durante os períodos inflacionários), as empresas nacionais tiveram de recorrer a novas formas de ajustes, seja pelo enxugamento, seja pela introdução de novas tecnologias, seja pela 
informalidade, seja pela ampliação de novas modalidades de contratação do trabalho ${ }^{17}$. Reconfiguravam-se, assim, as formas da flexibilidade do trabalho no Brasil.

No Estado de São Paulo, e em particular na região metropolitana de São Paulo, tais efeitos foram especialmente importantes por se somarem aos efeitos da reespacialização dos investimentos industriais, tanto em direção a outros estados, quanto em direção ao interior do próprio Estado. Além do desemprego, assistiu-se ao crescimento das vagas fornecidas por empresas intermediárias - especializadas na locação, agenciamento e seleção de mão de obra - num ritmo muito mais célere do que o crescimento do emprego formal como um todo.

Segundo Pochmann, (2007) entre 1985-2005, enquanto o total dos empregados formais no Estado de São Paulo cresceu quase uma vez e meia, o número de trabalhadores formais em empresas de intermediação "foi multiplicado por 7 vezes, passando de 60,5 mil para quase 424 mil ocupados" (Pochmann, 2007a, p. 12). Em termos relativos, dos três milhões de empregos formais que o Estado de São Paulo gerou durante vinte anos, "12,1 \% foi representado por ocupações (...) nos empreendimentos envolvidos com terceirização de mão-de-obra" (dados da RAIS/MTE e Guias de contribuições sindicais do SINDEEPRES ${ }^{18}$ apud. Pochmann, 2007, p.12).

Um crescimento não só quantitativo, mas também qualitativo, dado que a participação relativa das ocupações típicas das atividades auxiliares - que em 1985 representavam mais de $97 \%$ do total dos subcontratados paulistas - cai para $58 \%$ em 2005, elevando-se por sua vez, o peso das ocupações técnicas (mecânica, informática, telecomunicação), dos vendedores e dos trabalhadores da logística. Ou seja, sinais de que as contratações do setor de intermediação acompanhavam as mudanças que atravessava a economia como um todo (Pochmann, 2007, p. 16) ${ }^{19}$.

É certo que o governo FHC promoveu, a partir de 1996, uma série de medidas de proteção setoriais e um conjunto de programas sociais de transferência de renda, que complementados por uma mudança radical na política de câmbio (como a substituição do câmbio semi-fixo e sobrevalorizado pelo câmbio flutuante em janeiro de 1999)

\footnotetext{
${ }^{17} \mathrm{Ou}$ seja, com os produtos estrangeiros mais baratos, a indústria nacional não pôde subir os preços e aproveitar a recuperação dos rendimentos gerais promovida pela valorização da moeda.

${ }^{18}$ SINDEEPRES (Sindicato dos Empregados em Empresas de Prestação de Serviços a Terceiros, Colocação e Administração de Mão de Obra, Trabalho Temporário, Leitura de Medidores e Entrega de Avisos do Estado de São Paulo).

${ }^{19}$ Apesar das ocupações de faxineiro e de serviços de preservação continuarem sendo as mais representativas do universo dos trabalhadores terceirizados no Estado de São Paulo no ano de 2005 $(26,1 \%)$.
} 
aproximaram a fase final de seu governo daquilo que Sallum Jr. (2000) chamou de "liberal desenvolvimentismo". Efeitos se fizeram sentir no mercado de trabalho, sem entretanto uma reversão significativa de tendências; notadamente uma leve melhoria dos patamares de desemprego pode ser notada.

Tal estratégia desenvolvimentista foi levada adiante e adquiriu consistência durante o governo Lula (de 2003 em diante) assentada na melhoria do ambiente comercial externo e na ampliação do papel creditício do BNDES (Banco Nacional do Desenvolvimento Econômico e Social) ${ }^{20}$. Medidas que, já em 2004, começaram a surtir efeito em termos da sistemática recuperação do crescimento econômico e do mercado de trabalho formal. Nesse sentido, os números não deixam dúvidas: já em 2004, o crescimento do PIB atingiu 4,2 \%, o melhor resultado desde 2000 (IBGE, 2006), e só no mês de março foram gerados 185 mil empregos formais, também o melhor resultado desde 1992 (Ministério do Trabalho e do Emprego). Recordes positivos que, no ano de 2007, culminaram com a criação de 1,61 milhão de empregos formais, com o crescimento econômico de $6,1 \%$ do PIB e com o acúmulo de reservas que pela primeira vez na história ultrapassou os U\$\$ 100 bilhões (IBGE, 2008) ${ }^{21}$.

Desse modo, ao invés de especialização regressiva ${ }^{22}$, a economia brasileira demonstrava-se capaz de manter a competitividade das commodities primárias (agronegócio) e oferecer condições para que um moderno e seleto grupo de serviços e firmas industriais se desenvolvesse. Resultado reforçado pelos achados de Arbix (2008) que, já no ano de 2006, verificava a importância das indústrias de grande porte, as quais especializadas nas manufaturas de alta e média tecnologia (1.199, ou seja, apenas $1,7 \%$ do total das companhias industriais brasileiras) contabilizavam mais de $25 \%$ do total das vendas industriais e 14\% do emprego na indústria (Arbix, 2008, p. 9-10). Ademais, seus produtos já somavam $31 \%$ do total das exportações brasileiras e entre os quais se

\footnotetext{
${ }^{20}$ Aumentaram as dotações e reduziram as taxas de juros dos empréstimos de longo prazo (Martins, 2007, p.39).

${ }_{21}^{21}$ Dados extraídos de quadro apresentado na Revista Época de 21 de Dezembro de 2009, pp. 55- 56.

${ }^{22}$ Segundo Arbix (2006) os adeptos dessas perspectivas enfatizavam que a abertura financeira combinada com a redução da inflação, baseada na elevação das taxas de juros e na moeda supervalorizada, prejudicaria a competitividade da indústria brasileira. Nesse cenário, apenas as companhias cuja produção se apoiasse no emprego intensivo dos recursos naturais e da mão-de-obra seriam capazes de competir internacionalmente, enfraquecendo os setores de maiores valor adicionado e gerando a especialização regressiva (Coutinho, 1997; Kupfer, 1998; apud. Arbix, 2006).
} 
destacavam aeronaves, motores, fármacos, automóveis e equipamentos de comunicação (Idem, 2008, pp. 4-5) ${ }^{23}$.

Embora ainda minoritário, esse grupo seleto de empresas tinha potencial para transmitir seus efeitos positivos a outros setores da economia e da sociedade à medida que demandava mão-de-obra e serviços qualificados (escolaridade média de 9,13 anos de estudo) e investia cerca de $3 \%$ de seu faturamento em atividades de pesquisa e desenvolvimento (Arbix, 2008, pp. 9-10).

Entretanto, não deixa de ser paradoxal que a recuperação recente do emprego, sob o governo comandado pelo ícone do "novo sindicalismo", tenha sido em boa medida ancorada em relações de trabalho tradicionalmente associadas ao risco da perda de direitos (Guimarães e Souza, 2009a, p.24). Postura contraditória refletida inclusive nas práticas de contratação da administração pública federal que, durante todo o primeiro mandato do governo Lula, gastou $\mathrm{R} \$ 43,1$ bilhões com terceirizações - ou seja, 4\% a mais do que os $\mathrm{R} \$ 41,4$ bilhões dos últimos quatro anos do governo anterior - e aumentou o número de temporários de 15.588 para 23.403 (Guerzoni Filho, consultor legislativo do Senado, 2007, apud. O Estado de São Paulo, 08/10/2007) ${ }^{24}$.

Retomando o debate sobre flexibilização, a política de recuperação do valor real da moeda e o aumento da oferta de produtos importados inviabilizaram a continuidade da flexibilidade salarial. Submetidas a uma intensa pressão competitiva, muitas empresas tiveram de recorrer às estratégias de flexibilidade numérica externa ou a modernização tecnológica; ajustando as contratações de mão-de-obra às necessidades da demanda e pressionando os salários, dessa vez, pela ameaça do desemprego.

Todos esses fenômenos tornam pertinente investigar como esse avanço célere das contratações temporárias e terceirizadas, tanto no setor público quanto no setor

\footnotetext{
${ }^{23}$ Os outros 69\% das exportações distribuíam-se entre: 40\% de commodities primárias (agronegócio), $13 \%$ de bens manufaturados intensivos em trabalho e recursos naturais (setor têxtil, calçadista, móveis, vidro); $8 \%$ de bens manufaturados de baixa tecnologia (aço e ferro) e outros $8 \%$ das exportações não foram identificadas (IPEA, 2005, 2006; IBGE/Pintec, 2000. Produtos por intensidade tecnológica de acordo com a metodologia da UNCTAD, apud. Arbix, 2006, p. 5).

${ }^{24}$ Justiça seja feita, o governo Lula também aumentou consideravelmente as práticas de contratações de servidores por meio de concursos públicos e substituiu, segundo determinações do Ministério Público do Trabalho, diversos terceirizados por trabalhadores concursados. Um dos principais exemplos foi à extinção gradual de 9.229 postos terceirizados da Caixa Econômica Federal, os quais até junho de 2008 tinham sido substituídos por cerca 5.003 técnicos bancários aprovados nos concursos (Fonte: site do Ministério Público do Trabalho em 06/06/08). Apesar de todo esse esforço, é importante ressaltar que isso não reduziu, pelo contrário, até aumentou a contratação de temporários e terceirizados na administração pública federal (Ministério do Planejamento, 2007, apud. "O Estado de São Paulo", 08/10/07).
} 
privado, relaciona-se às mudanças no perfil das contratações e quais os efeitos desse movimento sobre os vínculos de trabalho e sobre os percursos no mercado laboral daqueles que ingressam ou retornam à atividade econômica por meio desse tipo de inserção no mercado formal. Esses serão os alvos da análise empírica que se apresentará nos capítulos subseqüentes. 


\section{Capítulo II}

\section{A SubContrataçÃo de Mão-DE-OBRA e AS AgênCias Privadas de Trabalho Temporário.}

De acordo com o capítulo anterior, a externalização de diversos estágios da produção, inclusive dos contratos da própria mão-de-obra utilizada internamente, foi estimulada pela abertura dos mercados, seguida da intensificação da concorrência.

Tais fenômenos - amplos e vagamente definidos, no discurso empresarial, como “externalizações", "terceirizações” ou "subcontratações" - eram partes das estratégias de competitividade e produtividade e correspondiam às necessidades de aumentar a flexibilidade e a capacidade de inovação num ambiente de mercado cujos consumidores dispunham de novas opções e variedade de produtos (Coriat,1992). Embora na prática os resultados sempre fossem discutíveis, as principais divergências entre os interpretes centraram-se mais na situação dos trabalhadores do que na própria estratégia de recorrer aos serviços oferecidos por empresas terceiras.

Assim, quanto mais as transferências de atividades envolviam a substituição de empregados diretos e regulares por trabalhadores externos e desafiavam as normas das relações de trabalho típicas da sociedade industrial, maior era a probabilidade de que tais práticas fossem associadas à precarização das condições de trabalho. Postura, entretanto, matizada pelos estudos sociológicos que analisavam o poder relativo dos atores no interior das organizações (Echeverría, 2001; Kalleberg e Marsden, 2005).

Seguindo essa linha de pesquisa, autores como Kalleberg e Marsden (2005) verificaram que as disputas e negociações entre acionistas, gerentes e trabalhadores em torno da eficiência econômica e da governabilidade das relações de trabalho conferiam ao fenômeno formas e resultados muito distintos; ou seja, que diferentes tipos de atividade eram desigualmente passíveis de externalização ("externalization") ${ }^{25}$, sendo comum a contenção de eventuais efeitos negativos e a combinação com $o$ desenvolvimento interno de outras atividades (Kalleberg e Marsden, 2005, pp. 391393).

\footnotetext{
${ }^{25}$ No artigo citado, Kalleberg e Marsden (2005) preferem utilizar o termo "externalization", ao invés de "outsourcing", isso porque, nas análises norte-americanas, esse último termo é geralmente empregado apenas para se referir às atividades que antes eram desenvolvidas no interior das organizações. Ou seja, demanda o conhecimento da história particular de cada organização e da atividade que nem sempre é acessível (Kalleberg \& Marsden, 2005, p. 390).
} 
Ademais, a partir das informações contidas no "National Organizations Study II" (II Estudo das Organizações Nacionais), de 1997 - um survey amostral realizado pelo Minnesota Center for Survey Research (MCSR) e representativo das organizações localizadas no território norte-americano - os autores constataram que, quanto mais a atividade se distanciava da finalidade principal da organização, maior era a participação dos intermediários e a probabilidade de que as tarefas fossem executadas de modo exclusivo pelos trabalhadores externos ${ }^{26}$.

Desse modo, apesar de $54 \%$ dos estabelecimentos confirmarem a contratação dos serviços prestados pelos intermediários do mercado de trabalho, eram significativas as diferenças observadas no seu uso. Enquanto nas atividades centrais os trabalhadores alocados (temporary workers) comumente suplementavam o serviço dos empregados regulares, nas atividades periféricas era muito provável que eles executassem as tarefas de modo independente, sob tutela quase exclusiva da empresa que os alocava (contract workers) (Kalleberg e Marsden, 2005, p. 409). Portanto, a freqüência e o tipo de serviço prestado variavam bastante de acordo com as características especificas da área e da organização em questão.

Esses resultados confirmavam a pertinência analítica dos cinco eixos permanência-transitoriedade, centralidade-periferia, especialidade-generalidade, internalidade-externalidade, intermediação-autonomia - propostos por Magdalena Echeverría (2001) durante estudo sobre a subcontratação nas maiores empresas chilenas das áreas de mineração, manufatura industrial e agricultura. Apesar de não organizá-los num modelo formal, tais eixos foram úteis para a autora sistematizar os principais achados da literatura e, ademais, permitiram distinguir e identificar a subcontratação em torno das seguintes variações: se atendia a uma necessidade permanente ou ocasional; se era parte das atividades centrais ou marginais; se exigia trabalhadores especializados ou genéricos; se era realizada no interior ou no exterior das empresas; se envolvia os intermediários ou o emprego direto de trabalhadores autônomos.

Dentre os resultados mais interessantes, Echeverría e outros destacaram, à semelhança da literatura brasileira e norte-americana, que a subcontratação via

\footnotetext{
${ }^{26}$ Segue-se a distribuição do uso dos intermediários de acordo com as áreas de atividade: atividades centrais $(9.5 \%)$; marketing $(5,3 \%)$; pesquisa e desenvolvimento $(13,5 \%)$; serviços de escritório $(13,5 \%)$; serviços de computação/informação $(23,4 \%)$; contabilidade $(26,7 \%)$; segurança $(57,1 \%)$; portaria $(42,3 \%)$; manutenção e reparos $(47,6 \%)$ (National Organizations Study II, apud. Kalleberg e Marsden, 2005, quadro da p. 403).
} 
intermediários, em importantes países da América da Sul, crescia e se acelerava justamente nos momentos em que o mercado de trabalho tornava-se mais instável, conservando sua trajetória ascendente mesmo nos períodos de recuperação econômica ${ }^{27}$. Assim, entre 1989 e 1997, a proporção de assalariados com contratos temporários no Peru aumenta de 29,4\% para os impressionantes 55,3\% e, no Chile somente no biênio 1994/1996 passa de 11,3\% para 17,4\% (Tokman e Martínez, 1999; apud, Echeverría, 2001a).

Mas, afinal, quem eram esses atores mediadores das relações de subcontratação? Que atividades os caracterizavam?

Segundo, D. Autor (2008):

"Os intermediários do mercado de trabalho (LMIs) são entidades ou instituições que se colocam entre trabalhadores e firmas para facilitar, informar, ou regular o modo pelo qual os trabalhadores são conectados as firmas, como o trabalho é realizado e como os conflitos são resolvidos" (Autor, 2008, p.1).

Para Benner, Leete e Pastor (2007), mais que exercerem a simples mediação, os intermediários combinam as funções de colocação, treinamento e suporte à carreira dos trabalhadores que intermediam. Assumiam distintos formatos organizacionais; entre eles os autores destacaram, tendo o caso norte-americano em vista: as agências privadas de trabalho temporário (temporary help agency), as agências públicas de colocação e assistência social, as agências organizadas pelos sindicatos, as organizações sem fins lucrativos (nonprofit organizations) e as comunidades universitárias (community colleges) (Benner et al, 2007, p.9-10).

Interessados em estudar a importância dessas organizações na operação de dois mercados de trabalhos regionais distintos - Milwaukee, em Wisconsin, protótipo da "antiga economia industrial" e, Vale do Silício, na Califórnia, protótipo da "nova economia informacional" - os autores realizaram um survey telefônico entre agosto de 2001 e junho de 2002, que indicou a centralidade assumida pelas agências privadas de trabalho temporário no funcionamento e na percepção geral sobre a atividade (Idem, 2007$, p.3 $)^{28}$.

\footnotetext{
${ }^{27}$ Annette Bernhardt (2001), por exemplo, comparando os indivíduos que entraram no mercado de trabalho em 1979 com os ingressantes em 1966, verificou que o crescimento dos intermediários coincide com o momento no qual a probabilidade dos indivíduos trocarem de emprego torna-se $30 \%$ maior, ou seja, a partir da década de 1970 (Bernhardt; apud. Benner, Leete e Dresser, 2007, p.6).

${ }^{28} \mathrm{O}$ survey entrevistou por telefone 1346 indivíduos (659 em Milwaukee e 689 no Vale do Silício) distribuídos entre os 25 e 65 anos de idade (Idem, 2007, p.21).
} 
Assim, embora 29, 8 \% dos entrevistados em Milwaukee e 26,3 \% no Vale do Silício tenham obtido pelo menos um emprego nos últimos três anos por meio dos intermediários, quase a metade deles resultou exclusivamente da intermediação de agências privadas de trabalho temporário. Ademais, em que pese houvessem trabalhadores mais qualificados entre os intermediados, o recurso aos intermediadores privados era mais freqüente entre os indivíduos mais vulneráveis (seja em termos de renda, educação ou raça). Resultado aparentemente positivo não fosse o fato de que essas mesmas agências estavam entre os intermediários que menos benefícios ofereciam em termos de treinamento, planos de saúde e previdência, o que em parte explicava o baixo nível de satisfação com a assistência recebida (Idem, 2007 p. 21).

Dada sua preponderância numérica entre os intermediários e o debate sobre seus efeitos, as agências privadas de trabalho temporário foram objeto de uma extensa literatura e muito se discutiu acerca de sua capacidade de oferecer oportunidades econômicas, principalmente aos indivíduos de baixo capital social (Autor \& Houseman, 2005; Anderson, Holzer \& Lane, 2005; Bohëim \& Cardoso 2007).

Nos Estados Unidos elas nascem em Chicago, ainda nos anos 1920, - com as primeiras agências fornecedoras de operadores de caixa de supermercado. Até 1956, seus empregados não chegavam a 20.000 em todo o país. Contudo, a partir de 1972, o setor do trabalho temporário passa, ali, por uma mudança significativa. Crescendo a uma taxa anual superior a 11\%, em vinte seis anos (de 1972-1998), a participação dos temporários no total dos empregos norte-americanos sai de $0,3 \%$ e chega próximo aos 2,5\%. Hoje as agências já chegam a representar cerca de $3 \%$ de todos os empregos da economia norte-americana (Gannon, 1984; Segal \& Sullivan, 1997, Laird \& Williams, 1996; apud. Kalleberg, 2000, p. 346).

Situação muito parecida com a experimentada por muitos países europeus. Ali, seu primeiro grande impulso deu-se na década de 1960, com a Holanda sendo o primeiro país a regulamentar a atividade em $1965^{29}$. A atividade avançou bastante nos últimos quarenta anos e, no início de 2000, os temporários chegavam a representar $20 \%$ da força de trabalho espanhola, 10\% na Alemanha, Países Baixos, Finlândia, Suécia e, 5\% na Itália e na Bélgica (Eurostat apud.Echeverría, 2001b, p. 21 e 30).

\footnotetext{
${ }^{29}$ Logo em seguida Irlanda (1971), França (1972), Alemanha (1972) e Inglaterra (1973) também regularam a atividade (Echeverría, 2001b).
} 
Já na América Latina o emprego temporário atravessa estágios de desenvolvimento muito distintos. De acordo com o país, desde sua introdução na década de 1960, as agências enfrentam a competição de fornecedores de mão-de-obra que muitas vezes se apóiam na categoria formal de "cooperativa" apenas para ocultar sua incapacidade de arcar com os tributos e justificar a redução salarial de seus trabalhadores; presentes em países como a Colômbia, Chile, Equador e Brasil, tais entidades vêm sendo combatidas pelos órgãos governamentais fiscalizadores do trabalho (Confederación Latinoamericana de Empresas de Trabajo Temporario y Afines, 1999; apud. Echeverría, 2001b, p. 23) ${ }^{30}$.

No Brasil, a atividade está regulamentada desde 1974. Uma exceção em relação aos seus principais vizinhos, que só a reconheceram a partir da década de 1990, com as reformas dos códigos trabalhistas na Colômbia (1990), Argentina (1991) e Peru $(1991)^{31}$. Assim, no início dos anos 2000, as agências empregavam cerca de 1.200.000 trabalhadores no Brasil, 350.000 na Colômbia, 50.000 na Argentina e 30.000 no Chile (Associación Gremial de Empresas de Servicios Temporarios, 2001; apud. Echeverría, 2001b. p. 7).

Quase todos os países que regularam a atividade procuraram garantir que ela fosse exercida por entidades solventes, com estruturas organizacionais adequadas, capazes de responder às obrigações salariais e tributárias. Ademais, com o intuito de assegurar que os serviços prestados fossem efetivamente temporários, transitórios e, de preferência, restritos às atividades meio, definiram-se regras e limites aos contratos, mais ou menos precisos de acordo com o contexto. Assim, na Bélgica, por exemplo, o trabalho temporário é de no máximo 6 meses; na Dinamarca, só pode chegar a 3; na Alemanha, se estende de 9 meses a 1 ano e, no Brasil, é de 3 meses podendo chegar a 6.

Apesar de importantes para consolidar a atividade, em alguns países tais restrições formais são, na prática, bastante flexíveis. Nesse sentido, o caso brasileiro pode ser especialmente ilustrativo. Embora a legislação obrigue a agência a se dedicar exclusivamente aos temporários, ela pode expandir suas atividades ao atendimento de

\footnotetext{
${ }^{30}$ No Brasil popularizou-se até um termo, "coopergatos", para diferenciar essas entidades irregulares das cooperativas legítimas. A presença maciça desses atores no mercado de intermediação em alguns casos estimula práticas ilegais, até mesmo das agências formais, com o intuito de se manterem competitivas.

${ }^{31}$ Segundo Echeverría, até 2001, Uruguai, Equador e Chile não tinham ainda uma legislação específica para regular a atividade. Entretanto, em todos eles, desde que respeitassem as normas gerais da legislação trabalhista, as agências contavam com permissão administrativa para desenvolver suas operações (Ameglio, E, 1999; apud. Idem, 2001b, p. 24).
} 
necessidades duradouras por alocar os trabalhadores como terceirizados. Essa prática tornou-se cada vez mais comum e, para evitar complicações com a Justiça do Trabalho, muitas agências registraram as atividades distintas com nomes diferentes, conservando endereço e estrutura organizacional comuns.

Tal complexidade não se restringe apenas à realidade brasileira. Nos EUA, há também muita dificuldade em capturar as diferenças ou em representar a complexidade dos intermediários por meio das distinções organizacionais. Segundo Benner, Leete e Pastor (2007), muitas agências de trabalho temporário moveram-se da simples colocação para fornecer uma ampla gama de serviços de gestão de recursos humanos. Para os autores, a partir da reforma dos programas de bem-estar, nos anos 1990, tornouse cada vez mais comum a parceria entre agências públicas e privadas. Ademais, até mesmo as organizações sem fins lucrativos e os sindicatos têm desenvolvido atividades comerciais para diversificar as fontes de financiamento e aumentar a credibilidade no setor privado (Carré et al. 2003; apud, Benner et al. 2007, p. 13) ${ }^{32}$.

Portanto, existe entre os intermediários uma mutação constante e uma intensa atividade relacional que reflete a busca em atender:

"Por um lado, a necessidades cada vez mais flexiveis (em termos numéricos e funcionais) de parte das empresas e, por outro lado, à busca de novas oportunidades ocupacionais por trabalhadores que ou haviam sido desligados depois de contratos duradouros em funções agora reestruturadas, ou eram (re) ingressantes no mercado de trabalho" (Guimarães, 2009a, p.97).

Pressupondo, em concordância com Guimarães (2009b, p.19), que tais necessidades variam segundo a maneira pela qual se institucionalizam, nas diferentes sociedades, os sistemas de emprego e de proteção social, procuro, a seguir, descrever um breve histórico do desenvolvimento das agências privadas de trabalho temporário no Brasil e os principais debates em torno de seu uso.

\footnotetext{
${ }^{32}$ Cabe esclarecer que em razão dos valores que orientam essas organizações e da condenação pela OIT desde 1949, não se cobra a atividade de agenciamento e colocação da mão-de-obra. Entretanto, os autores observaram que muitas vezes os sindicatos e as organizações sem fins lucrativos vendem, com descontos e preços acessíveis, alguns cursos de qualificação e treinamento específicos (Benner et al, 2007).
} 


\section{II.I - As agências privadas de trabalho temporário no Brasil.}

No Brasil, a atividade se inicia na Região Metropolitana de São Paulo, em 1963, a partir da instalação de uma franquia da multinacional "Manpower" 33.

Gerida inicialmente por um empresário holandês, logo a empresa norteamericana se desinteressa pelo mercado nacional e, em 1969, encerra suas atividades no país $^{34}$. Dotado de experiência e conhecimento, em 1970, seu antigo gestor funda uma nova empresa, a "Gelre Recursos Humanos". A Gelre torna-se a maior organização nacional do setor, cobrindo quase todo o território brasileiro, com mais de oitenta escritórios, e mantendo ainda uma unidade na Argentina ${ }^{35}$.

Apesar do começo desanimador, a atividade conseguiu se desenvolver e, num período de dez anos, emergiram novas empresas nacionais ao lado da chegada de outras empresas do exterior. Nessa época, enquanto a maioria das agências se especializava apenas no processo de recrutamento e seleção, outras seguiam o exemplo das empresas estrangeiras e forneciam também a administração do contrato dos trabalhadores temporários. Contudo, na ausência de uma regulação mais rigorosa da atividade, não demorou muito para que surgissem as primeiras contestações por parte das organizações sindicais e proliferassem desentendimentos em torno do assunto no interior da Justiça do Trabalho.

Assim, para conter a insatisfação social e restringir a concorrência, as principais empresas de intermediação se reuniram em 17 de março de 1970, e fundaram a primeira e até hoje única associação nacional do setor, a ASSERTTEM (Associação Brasileira de Empresas de Serviços Terceirizáveis e Trabalho Temporário). Naquele momento quatro empresas se destacaram - Gelre, Unicass, Madoti e Projac ${ }^{36}$ - e seus esforços iniciais concentraram-se na defesa do trabalho temporário e na promoção de sua regulamentação.

\footnotetext{
${ }^{33}$ Os relatos sobre a atividade no Brasil se baseiam nos depoimentos de importantes empresários do setor que participaram de entrevistas concedidas, entre os anos de 2004 a 2007, aos pesquisadores do projeto "A procura de trabalho. Instituições do trabalho e redes de sociabilidade" (São Paulo, USP/CEM/Cebrap), Fapesp/CNPq coordenado pela professora Nadya Araújo Guimarães.

${ }^{34}$ A ausência de um marco regulatório é reconhecida como fator que frustrou a tentativa inicial da Manpower no sentido de penetrar no mercado de trabalho brasileiro. Mais tarde, em 1978, quando o quadro normativo se completara, ela retorna, entretanto, associada a outro grupo (Guimarães, 2009, nota da p. 103).

${ }^{35}$ Conforme dados de 2007 obtidos no site: www.gelre.com.br.

${ }^{36}$ Dentre elas apenas a Gelre mantém suas operações; as demais faliram ou foram controladas por outros grupos.
} 
Após quatro anos de intenso trabalho institucional junto a políticos, governo e organizações classistas, a primeira vitória veio em 1974 com aprovação da Lei 6.019 que regulamentou o trabalho temporário e seu fornecimento. Desde então, todo trabalho que corresponde a uma necessidade transitória das empresas, seja por necessidade de substituição ou por elevação extraordinária da produção, passou a ser caracterizado como temporário. Com duração inicial de três meses, foi permitido que os contratos se renovassem por mais noventa dias, desde que autorizados pelos órgãos locais do Ministério do Trabalho.

No que concerne às agências, exigiu-se que tivessem objeto único, registro no Departamento Nacional de Mão-de-Obra (órgão subordinado ao Ministério do Trabalho), uma reserva inicial de capital e que assumissem as responsabilidades de empregadoras formais dos trabalhadores alocados. Ou seja, mesmo sem necessariamente assumir as funções de comando direto sobre os temporários (vale dizer, sem ordenar como as tarefas deveriam ser feitas), elas eram responsáveis pelo recolhimento das contribuições à previdência social e tinham que pagar salários e benefícios equivalentes aos dos trabalhadores que substituíam. Caso a agência falisse, a empresa cliente ou tomadora tornava-se responsável pelas obrigações (Zainaghi, 2006).

Portanto, essas regras garantiram estabilidade suficiente para que o setor e a atividade se expandissem ao longo dos anos. Ademais, à diferença dos EUA e dos países da Europa Ocidental, por aqui as empresas de trabalho temporário encontraram seu principal nicho constitutivo não na demanda empresarial, mas no atendimento a necessidades de pessoal por parte do Governo. Isso facilitou bastante o reconhecimento da atividade, uma vez que o Executivo, pressionado pelo controle sobre os gastos administrativos, meta do Governo que se seguiu ao Golpe de 1964, voltou-se crescentemente para os temporários, argüindo o alvo de maior eficiência dos novos contratados e a redução dos desperdícios com as supostas "regalias" dos funcionários públicos (Bicev, 2005; Guimarães, 2009a).

Embora as grandes construtoras nacionais (as quais cresciam rapidamente no contexto de expansão da infra-estrutura urbana) e as empresas multinacionais (com orçamentos apertados para contratações diretas) também fossem importantes para assegurar um volume elevado de contratos, a importância estratégica de ambas nem de longe se aproximava da importância do Governo Federal. Segundo o depoimento de um importante empresário do setor, mais tarde, interessado em empregar temporários por 
prazos superiores ao permitido e evitar o crescimento das ações judiciais, o executivo novamente pressionou e, aliado aos representantes das agências, conseguiu fazer com o que o Tribunal Superior do Trabalho, em 1986, regulasse a "locação de mão-de-obra", ou seja, a contratação de trabalhadores por longo prazo sob a forma de prestação de serviços terceirizados (informações sistematizadas anteriormente em Bicev, 2005, e Guimarães, 2009) ${ }^{37}$.

Assim, a partir da normatização promovida pela Súmula 256, posteriormente revista e substituída sem grandes alterações pelo Enunciado 331, de 1993, a atividade popularmente conhecida como "terceirização" foi formalmente restrita às funções auxiliares (vigilância, conservação e limpeza) e às atividades meio que não envolvessem pessoalidade, nem subordinação direta às firmas contratantes. Ademais, ao contrário do trabalho temporário, além de empregadoras formais, as agências ou prestadoras de serviço assumiam a condição de empregadoras diretas, responsáveis pela execução das tarefas e obrigadas a repor seus trabalhadores em caso de falta.

Portanto, num país cujo mercado de trabalho era bastante flexível (e em que tanto o empregado direto quanto o empregado externo seriam, a princípio, temporários no setor privado), foi a necessidade de flexibilidade de contratações por parte da administração pública que impulsionou a atividade. Ao invés da rigidez dos mercados, por aqui o que explica a necessidade de regulamentar o trabalho temporário e a aceleração das firmas encarregadas do seu fornecimento foi o interesse do governo, nos âmbitos federal, estadual e municipal em contar com trabalhadores suplementares ou auxiliares, sem passar pelos requisitos formais dos concursos.

Tal situação começa a se alterar entre as décadas de 1980 e 1990 quando o setor privado vai se tornando um cliente cada vez mais proeminente dos serviços das agências. Ainda no início dos anos 1990, esse aumento significativo da demanda promove um novo alinhamento e uma reorganização entre as empresas do setor da intermediação.

Assim, como os salários e os benefícios dos terceirizados deveriam ser definidos em convenção coletiva com sindicatos reconhecidos pelo Ministério do Trabalho, as agências reunidas sob a ASSERTTEM (que na época chegavam a mais de 130 associados) sentiram a necessidade de criar também dois sindicatos, um patronal e outro

\footnotetext{
${ }^{37}$ Por essa época, ações já aconteciam, inclusive contra o próprio Governo. Muitos ex-temporários, que haviam prestado serviços por um período excessivo, entravam na Justiça para reivindicar os mesmos direitos dos funcionários públicos.
} 
dos trabalhadores. Desse modo, em 1991, foi fundado o SINDEPRESTEM (Sindicato das Empresas de Prestação de Serviços a Terceiros, Colocação e Administração de Mão-de-obra e de Trabalho Temporário no Estado de São Paulo) e no ano seguinte, 1992, fundou-se o SINDEEPRES (Sindicato dos Empregados em Empresas de Prestação de Serviços a Terceiros, Colocação e Administração de Mão de Obra, Trabalho Temporário, Leitura de Medidores e Entrega de Avisos do Estado de São Paulo). Ambos, com participação ativa dos representantes patronais, constituíram-se em novas tentativas de restringir a concorrência e criar uma estabilidade suficiente para a realização dos negócios.

Entretanto, nessa mesma época, principalmente na segunda metade da década de 1990, concomitante ao aumento da terceirização formal ocorre também uma elevação significativa da informalidade que só vai ser contida a partir de 2004. Isso ofuscou bastante o interesse pelo estudo das agências, relegadas ao segundo plano na extensa literatura sociológica que buscou flagrar as irregularidades nas terceirizações que cresciam celeremente nos mais diversos setores e áreas de atividade (Martins \& Ramalho, 1994; Colli, 2000; Jinkings, 2002; Braga, 2006; Druck \& Franco, 2007; Dau, Rodrigues e Conceição, 2009).

Tal literatura documentou os efeitos da terceirização crescentemente no que concerne ao risco de redução salarial, às jornadas intensas e à perda de benefícios. Mas a atratividade dos intermediários se mantinha; eles cresceram em importância na intermediação entre as vagas de trabalho e os desempregados. Segundo Guimarães (2005), só na região metropolitana de São Paulo (RMSP), quase quatro em cada dez indivíduos $(39,8 \%)$ diziam, em 2001, buscar uma oportunidades de emprego através das agências privadas (Guimarães, 2005, 2009a) ${ }^{38}$.

Ademais, a partir do PLANFOR (Plano Nacional de Qualificação do Trabalhador), de 1996, e das experiências de gestão tripartite no emprego dos fundos públicos, com base no recurso do FAT (Fundo de Amparo ao Trabalhador), a atividade ganha o reconhecimento dos sindicatos e das centrais, que passam a receber recursos governamentais para financiar suas atividades, inclusive de intermediação (Guimarães 2009a, p. 106).

\footnotetext{
${ }^{38}$ Por meio de um questionário suplementar à PED (Pesquisa de Emprego e Desemprego) da fundação SEADE, levado a campo entre abril e dezembro de 2001.
} 
Portanto, se no início da década de 1970, as agências ou empresas privadas de trabalho temporário encontraram dificuldades no mercado, poucas décadas depois Bessa e Consoni (2007) verificaram, com base em dados de 2001, que as empresas do setor fundadas até o fim da década de 1980, apesar de apresentarem apenas 27,2\% das unidades, eram responsáveis por cerca de $54,5 \%$ do valor adicionado e $51 \%$ do total de empregos (Pesquisa de Atividade Econômica Paulista, PAEP-2001; apud. Bessa \& Consoni, 2007, p.9). Assim, a continuidade dos laços estabelecidos com as empresas tomadoras de serviços e a estrutura operacional constituída para o fornecimento de temporários parecem ter sido importantes para a manutenção dos negócios ${ }^{39}$.

No ano de 2006, segundo os dados da RAIS, havia 1.280 empresas formais de trabalho temporário e 27.655 empresas de serviços terceirizáveis espalhadas por todo o Brasil, e especialmente concentradas na Região Sudeste. Juntas essas empresas empregavam um total de 2.216.000 trabalhadores, e haviam se constituído no maior empregador formal do segmento de serviços do país. Com um faturamento anual de $\mathrm{R} \$$ 39,9 bilhões de reais, a massa salarial do setor correspondia a $\mathrm{R} \$ 17,4$ bilhões, sendo que os temporários recebiam em média $\mathrm{R} \$ 750,00$ reais e os terceirizados $\mathrm{R} \$ 600,00$ (Pesquisa Setorial, Sindeprestem, 2006-2007).

Desse modo, dada a dimensão e recente crescimento do setor, é imperioso investigar, como se faz nesse trabalho, o papel dessas agências, indagando sobre a natureza das oportunidades que elas têm criado principalmente para os jovens.

\section{II.II - As agências e o desempenho de quem acessa seus serviços.}

No ano de 1970, ao analisar como os moradores de um subúrbio de Boston encontravam empregos, Mark S. Granovetter, em sua dissertação de Doutorado “Changing Jobs: Channels of Mobility Information in a Suburban Community”, chegou aos seguintes resultados:

"Entre aqueles que encontravam um novo emprego por meio dos contatos pessoais, 16, 6\% disseram encontrar seu contato [ou seja, a pessoa que lhe passou a

\footnotetext{
${ }^{39}$ Os autores delimitaram o setor operacionalmente usando a categoria CNAE 74500 - "Empresas de colocação, agenciamento e seleção de mão-de-obra”.
} 
informação] com freqüência, 55, 6\%, ocasionalmente, e 27,8\%, apenas raramente $(N=54)$ " (Granovetter, 1970, apud. Granovetter, 1973, pp. 1371) $)^{40}$.

Embora naquela época já fosse difundia entre os sociólogos a idéia de que as redes pessoais eram importantes para a procura de trabalho, o que tornava seu achado interessante era a descoberta de que "o informante da oportunidade era muitas vezes alguém marginal na atual rede de contatos, tal como um velho amigo de escola ou do trabalho ou um antigo empregador, com os quais o beneficiário mantinha apenas um contato esporádico” (Granovetter, 1970, pp. 76-80, apud. Granovetter, 1973, p. 1372). Ademais, para os laços relacionados ao trabalho, muitos se encontravam apenas durante a jornada diária e quase nunca se relacionavam fora de seu contexto, sendo a participação em encontros profissionais ou reuniões de amigos fundamentais para a reativação de tais laços.

Por isso, o autor concluiu que os laços fracos eram tão importantes quanto os laços fortes para compreender como as redes sociais afetavam os fenômenos de difusão, mobilidade social, organização política e comunitária. Enquanto os laços fortes eram importantes para garantir a coesão dos grupos internos, os laços fracos eram fundamentais para trazer ou difundir informações e mediar às relações entre as idéias e os costumes de um grupo específico com a sociedade mais ampla ao seu entorno.

Esse trabalho de Granovetter estimulou novas pesquisas. Muitas delas indicaram que o papel informacional das redes era prejudicado nos casos de extrema pobreza e de círculos sociais restritos (Jargowsky, 1997; Pastor e Adams, 1996; apud. Benner et al., 2007, p. 14). Este tipo de achado, aliado à crítica aos programas públicos de primeiro emprego, contribuiu para estimular o conjunto de trabalhos produzidos voltados a investigar o potencial dos intermediários e sua capacidade de auxiliar os demandantes de baixa renda, cujas redes sociais eram fracas ou pouco efetivas para assegurar um emprego protegido (Harrison e Weiss, 1998; Johnson, Bienenstock, Farrel, 1999; Massey e Shibuya, 1995; Pastor e Marcelli, 2000, apud. Idem, 2007, p. $14)$.

Assim, entre as pesquisas mais recentes, destaca-se o trabalho de Autor e Houseman (2005). Os autores analisaram os dados dos beneficiados pelos programas

\footnotetext{
${ }^{40} \mathrm{O}$ autor definiu a freqüência a partir das seguintes categorias: freqüente $=$ ao menos duas vezes por semana; ocasionalmente = mais do que uma vez por ano, mas menos do que duas vezes por semana; raramente $=$ uma vez por ano ou menos (Granovetter, 1973, p.1371).
} 
TANF e "Work First" da cidade de Detroit" ${ }^{41}$ Verificaram que, no curto prazo (após três meses de entrada no programa), a média salarial dos trabalhadores encaminhados às agências de emprego temporário era superior à média recebida pelos trabalhadores alocados diretamente ${ }^{42}$. No entanto, num período mais longo (de um ano a dois) a situação se invertia e os mesmos temporários, quando não retornavam aos programas de bem-estar, tinham rendimentos mais baixos e empregos menos freqüentes que seus pares contratados de modo direto ${ }^{43}$. Resultados, esses, que prejudicavam a avaliação das agências na perspectiva das políticas públicas, uma vez que o principal objetivo era fazer com que os indivíduos se tornassem duradouramente independentes dos programas de bem-estar (Autor \& Houseman, 2005; p.27).

Segundo Anderson, Holzer e Lane (2007), tais achados, contudo, sofriam o limite de retratar apenas a realidade dos beneficiados pelo TANF e pelo programa de Primeiro Emprego de uma única cidade, Detroit, "deixando de fora um amplo leque de trabalhadores de baixa remuneração”. Ademais, a relação superficialmente explorada entre a elevação salarial momentânea dos temporários e sua participação na indústria local (cerca de 30\% dos temporários eram empregados na produção, contra pouco mais de $5 \%$ dos contratados diretos) ${ }^{44}$ fornecia indícios de que, apesar de insatisfatórias quanto aos objetivos da política pública, as empresas prestadoras de serviços temporários cumpriam sua função em oferecer "aos trabalhadores de baixa remuneração, acesso a firmas de padrões salariais mais elevados" (Andersson, Holzer e Lane, 2007, p.4).

Por isso, buscando ampliar o escopo da pesquisa, os autores realizaram um estudo (2007) a partir dos dados oriundos do programa "Dinâmicas Longitudinais do

\footnotetext{
${ }^{41}$ A sigla TANF significa "Temporary Assistance to Needy Families". Trata-se de um programa social do governo federal norte-americano que no estado de Michigan foi atrelado ao programa "Work First". Na cidade de Detroit o programa se organizou da seguinte maneira: em toda cidade há uma agência estatal que gerencia o TANF e outra local que gerencia o Work First; a cidade foi dividida geograficamente em nove distritos, nos quais estão distribuídos 25 organizações sem fins lucrativos ou do próprio setor público, subcontratadas pela agência local para oferecer treinamentos e auxiliar a procura de emprego. A participação nos cursos e a procura ativa de emprego por pelo menos $40 \mathrm{~h}$ semanais são condições para a continuidade dos benefícios. É importante ressaltar que a avaliação das entidades contratadas passa pelo número de colocações realizadas a cada 90 dias, e por isso mesmo, muitas delas acionam as agências privadas de trabalho temporário (Autor \& Houseman, 2005, pp 3-5).

${ }^{42}$ A análise foi realizada num período de três anos e meio entre 1999 a 2003 com um universo 36.000 indivíduos. Enquanto no segundo trimestre, após a entrada no programa, os temporários ganhavam em média $\$ 7,96$ por hora trabalhada, os empregados diretos ganhavam $\$ 7,47$ (Idem, 2005, p. 18).

${ }^{43}$ Cito: "no longo prazo, essas colocações não aumentam, e podem mesmo reduzir as chances dos participantes atingirem niveis salariais suficientes para deixar os programas de bem-estar e escapar da probreza" (Idem, 2005, p. 25).

${ }^{44}$ Autor e Houseman (2005) p. 18 e tabela da p. 38.
} 
Emprego e das Famílias" (LEHD), realizado pelo Bureau do Censo dos Estados $\operatorname{Unidos}^{45}$. A partir das informações oriundas dos cinco primeiros Estados que forneceram longos painéis de micro-dados sobre firmas e trabalhadores (Carolina, Flórida, Illinois, Maryland e Carolina do Norte), os autores extraíram uma amostra de quase 18 milhões de trabalhadores, operando aproximadamente em torno de 1 milhão de firmas por ano, durante o período de 1993-2001.

Composta por indivíduos que em 1993 tinham entre 25 e 54 anos (idade adulta), todos os integrantes da amostra tinham ainda um vínculo de trabalho e um rendimento mínimo em cada ano do período. Por meio de comparações entre a situação dos indivíduos no período inicial, definido entre 1993-1995, e a situação nos períodos posteriores $^{46}$, foi possível examinar a performance no mercado de trabalho dos indivíduos de baixa renda - ou seja, daqueles que durante três anos consecutivos ganharam 12 mil dólares ou menos por ano (e que foram denominados, pelos autores, de "persistently low earners"). Suas comparações sistemáticas apresentaram resultados importantes, dos quais quatro se destacam.

Em primeiro lugar, havia uma espécie de "auto-seleção positiva" entre os usuários das agências de trabalho temporário, ou seja, apesar da maioria ser composta por jovens e negros, havia maior probabilidade de que fossem do sexo masculino, nativos e tivessem características pessoais (escolaridade e qualificação) acima da média dos indivíduos com baixos rendimentos (Andersson, Holzer e Lane, 2007, p.15).

Em segundo lugar, observaram que a maioria dos trabalhadores que recorriam às agências durante o período base (1993-1995), não as utilizavam tanto durante o período de 1999-2001; o que não significava ausência de relações, pois "aproximadamente 40 por cento ainda a utilizavam em algum momento durante o período de 1996-1998, e um pouco mais de 1/4 (26.4\%) ainda a utilizavam entre 1999-2001" (Idem, 2007, p.16).

Um terceiro achado indicava que os ganhos atuais dos trabalhadores que passaram pelo emprego temporário no período base "são maiores do que os ganhos

\footnotetext{
${ }^{45}$ Tais dados apresentavam a vantagem de ter como fonte o registro trimestral dos rendimentos no Seguro Desemprego (UI) de 44 Estados e o Distrito de Columbia do início dos anos 1990 até o terceiro trimestre de 2006. Sem esquecer que "os relatórios trimestrais preenchidos pelos empregadores a cada trimestre para cada indivíduo coberto pelo emprego, permitem a construção de um banco de dados que fornecem informações longitudinais sobre trabalhadores, firmas, e a relação entre os dois" (Andersson, Holzer e Lane, 2007, p.5).

${ }^{46}$ Os outros períodos foram: 1996-1998 e 1999-2001.
} 
daqueles que possuíam baixa remuneração e não trabalharam para as agências de temporários anteriormente" (Idem, 2007, p.18) ${ }^{47}$.

O quarto e último achado importante reforçava o anterior, pela observação de que, nos períodos subseqüentes, os antigos temporários concentravam-se numa variedade de indústrias com padrões salariais mais elevados - notadamente na indústria de bens duráveis, mas também na construção civil, na produção de bens não-duráveis, nos transportes, comunicações e no comércio em geral ${ }^{48}$. Ou seja, "agora trabalham para empregadores que representam firmas com maiores efeitos fixos do que aqueles que não passaram pelas agências de emprego temporário” (Idem, 2007, p.20).

Portanto, enquanto para Autor e Houseman (2005) as agências eram incapazes de sustentar seus efeitos positivos no longo prazo, para Anderson, Holzer e Lane (2007) era justamente nos vínculos de trabalho subseqüentes que os efeitos positivos das agências faziam se sentir de modo mais saliente (Andersson, Holzer e Lane, 2007, p.20).

Sob impacto de ambas as conclusões e principalmente do quadro mais otimista retratado pelos últimos, Benner, Leete e Pastor (2007) retrabalharam seus dados sobre os trabalhadores temporários de Milwakee e Vale do Silício. Depois de rever seus resultados anteriores - principalmente aquele que indicava que em ambas as regiões " $o$ uso das agências temporárias era consistentemente associado com a redução do salário/hora e menor acesso a pensões e seguro saúde",49 -, os autores concluíram que o aumento salarial dos temporários, verificado no médio prazo, sugeria muito mais um aumento das horas trabalhadas do que do valor recebido por elas. Uma relação cuja investigação sistemática poderia resolver a aparente inconsistência entre os estudos.

Paralelamente ao debate norte-americano, o debate europeu também se esforçava para avaliar as agências de trabalho temporário enquanto promotoras da (re) inserção dos indivíduos no mercado formal e sua adequação aos serviços da chamada

\footnotetext{
47 Apesar de trabalharem menos trimestres para um empregador específico, "especificamente, aqueles que tiveram um emprego temporário intermediado pelas agências, em qualquer momento do período base, ganham agora 8-9 por cento a mais do que aqueles sem tal experiência, e 9-14 por cento a mais para o trimestre ou ano empregado" (Andersson, Holzer e Lane, 2007, p.18).

48 Cito: "entre 1996-98, 26\% dos antigos trabalhadores com baixos rendimentos, que passaram pelo emprego temporário no período base, conseguiram empregos em indústrias que apresentam padrões salariais mais elevados, comparados com apenas 18\% dos antigos trabalhadores de baixa renda sem passagem pelo emprego temporário . Entre 1999-2001 as proporções eram praticamente as mesmas, 28\% versus 19\%" (Andersson, Holzer e Lane, 2007, p.20).

${ }^{49}$ Relação sustentada mesmo depois de controlar pelas características detalhadas dos trabalhadores e do emprego (Benner, Leete, Pastor, 2007, p. 22).
} 
economia do conhecimento. Assim, também contribuíam com novos achados e elementos interessantes para a compreensão do fenômeno.

Em função da proposta da Comissão Européia em desenvolver uma regulação única para a atividade em todo o continente (European Commission, 2002), Forde e Slater (2005) registraram uma perda salarial de aproximadamente $11 \%$ para os homens e 6\% para as mulheres alocadas pelas agências de trabalho temporário no Reino Unido. O que deixava evidentes suas desvantagens em relação aos trabalhadores permanentes, em condições semelhantes em termos de ocupação e atributos pessoais (Forde e Slater, 2005, p. 18) ${ }^{50}$.

Böheim e Cardoso (2007) também verificaram uma perda salarial para os trabalhadores das agências em Portugal, os quais ganhavam em média 9\% menos que seus pares diretamente contratados. No entanto, o fator geracional possuía, ali, um forte peso na explicação. Numa análise mais minuciosa, os autores descobriram que "trabalhadores jovens, homens e mulheres", ganhavam "salários mais altos nas TAW [Temporary Agencies Works] do que seus pares em outras firmas", enquanto ocorria o "oposto aos adultos e aos trabalhadores idosos [principalmente do sexo masculino]" (Böheim \& Cardoso, p.4) $)^{51}$.

Portanto, as agências pareciam ter efeitos salariais distintos para indivíduos de gênero e faixas etárias diferentes. Embora os jovens entre 16 e 24 anos também fossem os principais usuários das agências britânicas, Forde e Slater (2005) concluíram que os efeitos da idade se dispersavam em razão da predominância das ocupações típicas das atividades de escritório e operações de rotinas $^{52}$, as quais juntas contabilizavam mais de 2/3 de todas as colocações realizadas no Reino Unido (Forde e Slater, Idem, p.12).

Outro tema bastante discutido no contexto europeu foi o da transição para o emprego permanente. Enquanto Forde e Slater verificavam que apenas 48\% dos

\footnotetext{
${ }^{50}$ As conclusões dos autores foram retiradas do "Labor Force Survey", uma pesquisa nacionalmente representativa, trimestral (desde 1993) com uma amostra de 60.000 famílias distribuídas por todo o Reino Unido (Forde e Slater, 2005, p10).

${ }^{51}$ Observam também que, antes de recorrer aos serviços dos intermediários (Temporary Help Services, THS), os trabalhadores adultos e idosos, tanto homens quanto mulheres, sofreram uma deterioração salarial relativamente aos seus pares, sugerindo que as condições adversas do mercado de trabalho podem motivá-los a procurar pelos empregos nas THS. O mesmo não foi detectado em relação aos jovens.

${ }^{52}$ Destacam-se escriturários, secretárias, contadores, entregadores, embaladores, digitadores. Juntas essas seis ocupações contabilizam cerca de $40 \%$ de todas as colocações (Labor Force Survey, 2000, apud. Forde e Slater, 2005, p.12).
} 
temporários britânicos conseguiam um emprego permanente no período de um ano ${ }^{53}$, na Alemanha, Kvasnicka (2008) - a partir dos registros da Agência Federal do Emprego verificava que as agências privadas de trabalho temporário reduziam consideravelmente o risco do desemprego, sem que necessariamente facilitassem o acesso ao emprego duradouro. Ou seja, embora os temporários tivessem maiores chances de adquirir novos empregos temporários, a probabilidade de encontrarem um emprego permanente entre 1994 e 2001 era quase a mesma dos desempregados. Ademais, o retorno ao mercado de trabalho, na maioria das vezes, se dava por uma agência diferente, uma vez que a legislação alemã era rigorosa quanto à renovação dos vínculos temporários (Kvasnicka, 2008, p. 29).

Situação semelhante foi encontrada por Amuedo-Dorantes, Malo e MuñozBullón (2006) na Espanha, onde a proibição legal da intermediação de trabalhadores permanentes restringia o efeito positivo da intermediação via agências apenas para a transição desemprego-temporário, temporário-temporário (Amuedo-Dorantes, Malo e Muñoz-Bullón, 2006, p. 18) ${ }^{54}$.

Por outro lado, num estudo sobre os trabalhadores da Manpower em duas regiões italianas - uma central, Toscana, e outra ao sul, Sicilia - Ichino, Meali e Nannicini (2005) chegaram a resultados distintos. Num período de 18 meses, compreendidos entre 2001 e 2002, os autores verificaram que, comparados aos trabalhadores atípicos e desempregados, a passagem pelas agências aumentava em 19 pontos percentuais a chance de obter um emprego permanente na Toscana e em 11 pontos tal chance na Sicilia. No entanto, na Toscana (região na qual os efeitos das agências mostraram-se estatisticamente mais robustos), os principais beneficiados eram indivíduos com mais de 30 anos, muitos com grau universitário completo (a pequena minoria dos temporários) que se mantinham no setor de serviços (Ichino, Meali e Nannicini, 2005, pp. 24-25).

Portanto, inexistem evidências robustas de que as agências prejudicam a carreira futura dos temporários; mas, tampouco pode-se afirmar que elas facilitem o acesso ou

\footnotetext{
${ }^{53}$ De resto, $38 \%$ continuavam como temporários, 7\% tornavam-se desempregados e outros $7 \%$ entravam na inatividade (Forde e Slater, idem, p. 21).

${ }^{54}$ Essa pesquisa foi realizada a partir dos registros oficiais dos contratos espanhóis fornecidos pelo Serviço Público de Emprego do país. Os autores extraíram uma amostra com as informações dos indivíduos contratados de modo formal entre 1998 até 2004.
} 
ofereçam empregos melhores do que os indivíduos seriam capazes de adquirir por conta própria (Autor, 2008, p. 28) ${ }^{55}$.

Diante desse debate internacional, que se pode dizer sobre o impacto das agências na operação do mercado de trabalho brasileiro?

No Brasil, um dos primeiros estudos voltados à compreensão do crescimento e funcionamento sistemático das agências privadas foi realizado por Pamplona, no ano de 2002. Nesse estudo, concentrado na região do ABC paulista, o autor verificou que o setor industrial era o principal usuário dos serviços das agências, sendo que mais de $70 \%$ das unidades mantinham ao menos um trabalhador alocado nas indústrias da região, seguido do comércio (50\%), dos serviços de saúde (29\%), dos bancos (17\%) e do governo (10\%). Outro achado importante sugeria que o setor era controlado pelas agências de grande porte (ou seja, com 100 ou mais empregados) as quais representavam cerca $47 \%$ dos estabelecimentos, $87,2 \%$ do pessoal ocupado e $84,9 \%$ do faturamento bruto acumulado no ano 2000 (Pesquisa da Atividade do Setor de Serviços Empresariais no Grande ABC- PASSE/ABC apud. Pamplona, 2002) $)^{56}$.

Mais tarde, Bessa e Consoni (2007) expandiram a pesquisa setorial de Pamplona para todo o Estado de São Paulo, mobilizando para isso os dados da Pesquisa de Atividade Econômica Paulista, relativa ao ano de 2001(PAEP-2001). Contando agora com um universo total de 2.989 empresas, os autores verificaram que o pessoal ocupado continuava concentrado nas agências de grande porte, as quais representavam apenas 9\% do universo total, mas empregavam $73,6 \%$ do pessoal ocupado.

No entanto, importantes diferenças eram notadas a partir das informações referentes ao faturamento do setor. Enquanto no $\mathrm{ABC}$ o faturamento continuava concentrado nas agências de grande porte, em todo Estado, especialmente na Região Metropolitana de São Paulo, a participação relativa dos grandes empreendimentos caía para cerca de 30 por cento, sugerindo para os autores que:

"se por um lado, os segmentos tradicionais mesmo caracterizados pelo agenciamento de trabalhadores em ocupações de baixa qualificação, mostram uma estrutura baseada em empresas de grande porte; por outro, as empresa menores,

\footnotetext{
${ }^{55}$ Cabe explicitar que quase todos os estudos citados retiraram suas conclusões a partir de refinadas técnicas estatísticas, a mais utilizada foi à análise de correspondência.

${ }^{56}$ Esse estudo foi um dos primeiros a analisar as agências a partir das informações reunidas no grupo 74500 do Código Nacional das Atividades Econômicas (CNAE-95), ou seja, Empresas de serviços de seleção, agenciamento e locação de mão-de-obra. Na região do $\mathrm{ABC}$, essas agência formavam um universo de 113 estabelecimentos, os quais se distribuíam (Pamplona, 2002, p.6).
} 
mesmo com baixa densidade de capitais, são capazes de prover serviços ultra especializados de alto valor agregado vinculados à gestão das grandes corporações" (Bessa \& Consoni, 2007, pp. 13-14).

Essa dimensão da atividade mais saliente quando se observa uma região maior, caracterizada pela diversidade de sua economia, têm estimulado um conjunto de trabalhos destinados a investigar a correlação existente entre a atividade de intermediação e as inovações organizacionais. Enquanto alguns verificam se as agências são capazes de gerar novos serviços e alocar trabalhadores qualificados, outros investigam a capacidade das agências assumirem as atividades auxiliares, sem prejuízo para as atividades-fins das empresas contratantes (Montagner, Bernardes e Matteo, 1999; Consoni, 2009)

Outro grupo de importantes trabalhos voltados à caracterização e funcionamento das agências surgiu a partir do achado de Guimarães (2005) de que, em 2001, elas já representavam o terceiro recurso mais empregado pelos indivíduos que procuravam trabalho na Região Metropolitana de São Paulo. Ou seja, embora pouco relevantes em termos da procura bem sucedida, chamava a atenção de que, ao lado da mobilização das redes pessoais e do contato direto com os empregadores, quase quatro em cada dez desempregados $(39,8 \%)$ buscavam uma oportunidade de trabalho através das agências privadas (Guimarães, 2005, p.11) ${ }^{57}$.

Depois de uma série de estudos destinados a dimensionar e caracterizar o setor, a autora concluiu que um amplo e sólido sistema de intermediação consolidou-se na Região metropolitana de São Paulo, onde, além dos demandantes de trabalho, estavam implantados todos os agentes da intermediação, privados e públicos. Estes operavam sobre uma sorte de rationale operacional diferente: enquanto as agências privadas especializavam-se na captação de vagas, as mantidas com o recurso público (governamentais e sindicais) pareciam especializadas em atrair demandantes de emprego (Guimarães, 2009, pp. 111-112).

Mais recentemente, a autora procurou identificar os percursos típicos daqueles que passaram pelos serviços de intermediação entre 1996 a 2002. A partir dos dados longitudinais da RAIS, especialmente do banco da RAIS-Migra, e por meio de análises fatoriais, oito percursos se destacaram:

\footnotetext{
57 Resultados obtidos por meio de um questionário suplementar à PED (Pesquisa de Emprego e Desemprego) da fundação SEADE, levado a campo entre abril e dezembro de 2001.
} 
TABELA II. 1: Percursos típicos dos que estiveram ocupados nas empresas de locação, agenciamento e seleção (Região Metropolitana de São Paulo: painel prospectivo dos ocupados em 1996, acompanhados até 2002)

\begin{tabular}{lcc}
\hline Percursos típicos & N & $\%$ \\
\hline 1. Fora da RAIS & 52.722 & 36,8 \\
2. Indústria de Transformação & 19.418 & 13,5 \\
3. Serviços Prestados às empresas & 18.813 & 13,1 \\
4. Intermediação & 16.088 & 11,2 \\
5. Comércio & 14.168 & 9,9 \\
6. Construção Civil & 9.697 & 6,8 \\
7. Transporte e Comunicação & 6.494 & 4,5 \\
8. Administração Pública & 5.914 & 4,1 \\
\hline Total & 143.314 & 100 \\
\hline
\end{tabular}

Fonte: Ministério do Trabalho e do Emprego. Painel RAIS-Migra, corte especial para a Região Metropolitana de São Paulo, Período 1996-2002. (Apud Guimarães, 2009, p. 59).

O principal deles era o "de saída duradoura do mercado formal de trabalho" que atingia "quase 4 em cada 10 desses trabalhadores". Logo em seguida destacavamse dois outros tipos de trajetos, por um lado, estavam aqueles que logravam sair do setor de intermediação em direção a empregos duradouros. Por outro lado, havia aqueles trabalhadores que permaneciam contratados por intermediários (Guimarães, 2009c, p. 59). Esses resultados eram importantes porque, assim como observado em outras realidades, via-se também na realidade da maior metrópole brasileira que o segmento de intermediação parecia propiciar acessos a empregos relativamente estáveis a uma parcela importante dos que por ele passavam, notadamente na indústria e nos serviços prestados a empresas (Autor e Houseman, 2005; Anderson, Holzer e Lane, 2007; Ichino, Meali e Nannicini, 2005).

Ademais, ao observar de modo retrospectivo o movimento daqueles empregados pelo setor em 2002, foi possível verificar que mais da metade dos trabalhadores recrutados haviam estado, antes, na informalidade, sendo que o movimento de (re) inserção no mercado formal benefíciava cinco em cada dez indivíduos (Guimarães, 2009c, p. 61). Isso sugeria que os efeitos da saída duradoura do mercado formal em 1996 eram em parte compensados e que o movimento refletia em especial o trajeto dos jovens e adolescentes com escolaridade de nível médio, os quais procuravam uma porta de entrada no mercado de trabalho. 
Esse tipo de análise abria novas perspectivas de pesquisa e fornecia uma descrição geral dos percursos dos trabalhadores que passavam pelas empresas de locação, agenciamento e seleção de mão-de-obra (ou de como venho chamando até agora de agências privadas de trabalho temporário). Entretanto, que mais se poderia dizer se fossem observados os mesmos percursos sob a perspectiva dos vínculos? Aqueles que são inseridos como temporários migram para os contratos CLT por tempo indeterminado? E se acompanhássemos o trajeto dos temporários empregados pelas agências com os temporários contratados diretamente pela indústria? O percurso se altera? São a partir dessas e outras questões que pretendo avançar no debate. 


\section{Capítulo III}

\section{Os Trabalhadores Intermediados na Região Metropolitana de São Paulo.}

Como demonstrado no capítulo anterior existe um forte interesse na literatura internacional e nacional em investigar os efeitos da inserção laboral mediada pelas agências sobre os vínculos estabelecidos e sobre as trajetórias dos trabalhadores no mercado de trabalho. Desse modo, o capítulo que se inicia é construído a partir de dois eixos.

No primeiro caracterizo o perfil e identifico os principais percursos ocupacionais dos trabalhadores que num período recente se inseriram ou retornaram ao mercado formal por meio das empresas de seleção, agenciamento e locação de mão-de-obra ${ }^{58}$. E no segundo, avalio o desempenho desses trabalhadores, quanto ao tipo de vínculo e ao setor ocupado; realizando, para isso, uma comparação entre os percursos obtidos e os percursos dos trabalhadores ocupados em outras atividades tipicamente subcontratadas, notadamente na limpeza e na vigilância.

Assim, para levar adiante a análise proposta, em primeiro lugar, procurei acessar as informações oriundas da RAIS (Relatório Anual de Informações Sociais), disponibilizadas em forma de micro-dados pelo Ministério do Trabalho e do Emprego brasileiro. Inspirado em análises anteriores (Guimarães, 2009c), dentre as diversas modalidades da RAIS (RAIS-estabelecimentos, RAIS-trabalhador, Séries históricas), optei por utilizar sua modalidade Migra (RAIS-Migra) pela vantagem de ser organizada em forma de painel e permitir estudos longitudinais sobre a mão-de-obra empregada no interior do mercado de trabalho formal ${ }^{59}$.

Em seguida, decidi observar longitudinalmente uma coorte de trabalhadores, a dos que em 1998 se inseriram ou retornaram ao mercado formal por meio das empresas de seleção, agenciamento e locação de mão-de-obra, de modo a identificar seu perfil e seu percurso ocupacional até 2007; ou seja, acompanhei nove anos da vida profissional desses indivíduos, de modo a verificar quão duradoura era sua condição de temporário e

\footnotetext{
58 Empresas da classe 74500 da Classificação Nacional de Atividades Econômicas de 1995 (CNAE95/IBGE).

59 Constituindo-se num registro administrativo destinado principalmente ao controle da arrecadação e concessão de benefícios pelo Ministério da Previdência Social, seu acesso nos fornece informações sobre o perfil (faixa etária, grau de instrução, gênero, ocupação e etc.) e sobre o tipo de vínculo da mão-de-obra empregada; todos esses dados disponibilizam-se desagregados por tamanho dos estabelecimentos, pelo setor de atividade econômica, pela natureza jurídica do empreendimento e pela localização geográfica.
} 
se, uma vez movendo-se, em que direção o faziam. E, por fim, comparei o desempenho dos temporários ocupados pelas agências com o desempenho de outras quatro coortes de trabalhadores; ou seja, com a coorte dos temporários contratados diretamente pela indústria da transformação, com a dos trabalhadores da limpeza, da vigilância e de outras atividades de serviços prestados principalmente às empresas.

Além das razões relativas à disponibilidade dos dados, ${ }^{60}$ a escolha do período mostrou-se também analiticamente interessante por contemplar um momento de transição, fim de um ciclo de elevação do desemprego e o início da retomada do crescimento econômico e dos empregos formais. A seguir dou início à apresentação dos principais resultados, começando pelas informações sobre o perfil.

\section{I - O perfil dos empregados nas empresas de seleção, agenciamento e locação de mão-de-obra.}

No ano de 1998, as empresas de serviços de seleção, agenciamento e locação de mão-de-obra empregavam, só na Região Metropolitana de São Paulo, um total de 166.571 trabalhadores. Entre eles, havia um claro predomínio dos trabalhadores do sexo masculino, que representavam 6 em cada 10 dos ocupados (Tabela III.1).

TABELA III. 1: Sexo dos trabalhadores ocupados nas empresas de seleção, agenciamento e locação de mão-de-obra, em 1998.

\begin{tabular}{c|c|c}
\hline SEXO & $\mathbf{N}$ & $\%$ \\
\hline Masculino & 102.659 & 61,6 \\
Feminino & 63.912 & 38,4 \\
\hline Total & 166.571 & 100,0 \\
\hline
\end{tabular}

Fonte: Ministério do Trabalho e do Emprego. Painel RAIS-Migra, corte especial para a Região Metropolitana de São Paulo, Período 1998-2007(processamento próprio).

Ademais, este é um mundo de oportunidades criadas significativamente para os mais jovens: assim, 40\% dos empregados através dos intermediários de oportunidades ocupacionais tinham entre 18 e 24 anos; se considerarmos uma definição um pouco mais ampla de "juventude", levando-a, como em outros países, até os 29 anos, veremos

\footnotetext{
${ }^{60}$ Esse é o maior e mais recente intervalo de tempo de que pude dispor, em micro-dados do sistema RaisMigra, no momento do preparo desta dissertação, tendo como unidades de observação os trabalhadores formalmente contratados da região metropolitana de São Paulo. Agradeço ao Centro de Estudos da Metrópole, para quem os dados foram inicialmente produzidos, pela disponibilização dos mesmos para meu uso.
} 
que 6 em cada 10 trabalhadores ocupados em São Paulo, via intermediários, seriam classificáveis como “jovens” (Tabela III.2).

TABELA III. 2: Distribuição etária dos trabalhadores ocupados nas empresas de seleção,agenciamento e locação de mão-de-obra, em 1998.

\begin{tabular}{c|c|c}
\hline FAIXA ETÁRIA & $\mathbf{N}$ & $\%$ \\
\hline 65 ou mais & 276 & 0,2 \\
50 a 64 & 4.966 & 3,0 \\
40 a 49 & 15.751 & 9,5 \\
30 a 39 & 38.868 & 23,3 \\
25 a 29 & 35.550 & 21,3 \\
18 a 24 & 66.982 & 40,2 \\
15 a 17 & 3.645 & 2,2 \\
10 a 14 & 144 & 0,1 \\
Ignorado & 389 & 0,2 \\
\hline Total & 166.571 & 100,0
\end{tabular}

Fonte: Ministério do Trabalho e do Emprego. Painel RAIS-Migra, corte especial para a Região Metropolitana de São Paulo, Período 1998-2007(processamento próprio).

Consistente com esse perfil, a grande maioria tinha a escolaridade típica dos jovens, compreendida entre o ensino fundamental incompleto e médio completo (Tabela III.3).

TABELA III. 3: Escolaridade dos trabalhadores ocupados nas empresas de seleção, agenciamento e locação de mão-de obra, em 1998.

\begin{tabular}{|c|c|c|}
\hline ESCOLARIDADE & $\mathbf{N}$ & $\%$ \\
\hline Analfabeto & 3.880 & 2,3 \\
\hline Fundamental Incompleto & 51.069 & 30,7 \\
\hline Fundamental Completo & 36.267 & 21,8 \\
\hline Médio Incompleto & 20.341 & 12,2 \\
\hline Médio Completo & 44.634 & 26,8 \\
\hline Superior Incompleto & 6.044 & 3,6 \\
\hline Superior Completo & 4.246 & 2,5 \\
\hline Ignorado & 90 & 0,1 \\
\hline Total & 166.571 & 100 \\
\hline
\end{tabular}

Entretanto, tão reveladores quanto os dados sobre o perfil dos indivíduos são os dados sobre a relação de trabalho que estabelecem, como sejam o tipo de admissão e o tipo de vínculo. A partir deles foi possível verificar que a grande maioria dos empregados das agências $(76,3 \%)$ já tinha tido ao menos uma experiência de trabalho 
formal e as utilizavam, principalmente, para se reinserir no mercado formal (tabela III.4).

TABELA III. 4: Tipo de admissão dos trabalhadores ocupados nas empresas de seleção, agenciamento e locação de mão-de-obra, em 1998.

\begin{tabular}{c|c|c}
\hline TIPO DE ADMISSÃO & N & $\%$ \\
\hline Reemprego( $\left.{ }^{*}\right)$ & 127.135 & 76,3 \\
Admitido Anteriormente $(* *)$ & 34.420 & 20,7 \\
Primeiro emprego & 4.744 & 2,8 \\
Outros $\left({ }^{* * *}\right)$ & 221 & 0,1 \\
Ignorado & 51 & 0,0 \\
\hline Total & 166.571 & 100,0 \\
\hline
\end{tabular}

Fonte: Ministério do Trabalho e do Emprego. Painel RAIS-Migra, corte especial para a Região Metropolitana de São Paulo, Período 1998-2007(processamento próprio).

* Admissão de empregado com emprego anterior.

** Trabalhadores cujo vínculo de trabalho atual se deu num ano anterior ao ano de referência.

***Transferências com ou sem ônus.

Igualmente significativo é observarmos a condição em que os mesmos estavam ocupados (Tabela III. 5). Eles eram dominantemente temporários (7 em cada 10 dos ocupados), mas não era desprezível o peso dos que tinham um vinculo formal ordinário, regido pela CLT (que perfaziam pouco mais que um quarto dentre os ocupados). Outras situações formalmente possíveis, como contrato por tempo determinado, o trabalho avulso, ou mesmo aparentemente adequadas à absorção dos mais jovens (como a de menor aprendiz) eram virtualmente insignificantes.

TABELA III. 5: Tipo de vínculo dos trabalhadores ocupados nas empresas de seleção, agenciamento e locação de mão-de-obra, em 1998.

\begin{tabular}{c|c|c}
\hline TIPO DE VínCULO & $\mathbf{N}$ & $\%$ \\
\hline Temporário & 119.522 & 71,8 \\
CLT & 46.632 & 28,0 \\
Outros( $\left.{ }^{*}\right)$ & 417 & 0,2 \\
\hline Total & 166571 & 100 \\
\hline
\end{tabular}

Fonte: Ministério do Trabalho e do Emprego. Painel RAIS-Migra, corte especial para a Região Metropolitana de São Paulo, Período 1998-2007(processamento próprio).

*Contrato por prazo determinado, trabalhadores avulsos, estatutários, diretor, menor aprendiz.

É interessante sublinhar um aspecto: a juventude não significava necessariamente inexperiência, uma vez que 75,9\% dos jovens entre 18 e 24 anos, ocupados através desses intermediários, já tinham passado pelo emprego formal. Isso conflui para achado de Echeverría (2001a) que, examinando o caso chileno, havia sugerido que, ali, as agências, antes de qualificarem, optam por recrutar trabalhadores 
(temporários ou permanentes) já treinados ou formados em outros setores e regiões industriais (Echeverría, 2001a, p. 10).

Embora fossem muito poucos aqueles que ganhavam apenas um salário mínimo, os rendimentos de cerca de $60 \%$ dos trabalhadores não passavam de quatro salários (Tabela, III. 6).

TABELA III. 6: Faixa salarial dos trabalhadores ocupados nas empresas de seleção, agenciamento e locação de mão-de-obra, em 1998.

\begin{tabular}{c|c|c}
\hline SALÁRIOS MíNIMOS (R\$ 130,00) & $\mathbf{N}$ & $\%$ \\
\hline 0-1 Salário & 5.817 & 3,5 \\
1,01 a 2 Salários & 23.490 & 14,1 \\
2,01 a 3 Salários & 47.836 & 28,7 \\
3,01 a 4 Salários & 30.304 & 18,2 \\
4,01 a 5 Salários & 15.292 & 9,2 \\
5,01 a 7 Salários & 15.034 & 9,0 \\
7,01 a 10 Salários & 8.568 & 5,1 \\
Mais de 10 Salários & 9.446 & 5,7 \\
Ignorado & 10.784 & 6,5 \\
\hline \multicolumn{2}{c}{ Total } & 166.571 \\
\hline
\end{tabular}

Ademais, a média dos salários pagos pelo setor era de 4,1 salários mínimos, o que na época (dezembro de 1998) representava algo em torno de $\mathrm{R} \$ 533,00$.

Há fortes indícios de que esse grupo de trabalhadores, relativamente mais jovem do que a força de trabalho como um todo, segue um padrão de trajetória marcado por intensas transições em ocupações que constituem a base inferior do mercado de trabalho. Fenômeno, esse, típico do início da vida profissional, que, segundo Guimarães (2009), generalizou-se ao longo da década de 1990 na Região Metropolitana de São Paulo e, que vem crescendo, principalmente, em sociedades onde o sistema de seguridade social é restrito.

\section{II - As trajetórias de trabalho dos empregados nas empresas de seleção, agenciamento e locação de mão-de-obra.}

Observando as possíveis mudanças ao longo do tempo, chama a atenção que num período de nove anos (1998-2007), 52,1\% dos temporários ocupados pelas agências tenham transitado para os contratos CLT por tempo indeterminado, sendo que 
quase quatro em cada dez $(39,3 \%)$ tornaram-se, em tese, trabalhadores permanentes ao final do primeiro ano (Tabela III.7, a seguir).

TABELA III. 7: Vínculos subseqüentes dos temporários ( $\mathrm{N}=119.522)$ que em 1998 estavam ocupados nos serviços de seleção, agenciamento e locação de mão-de-obra.

\begin{tabular}{|c|c|c|c|c|c|c|c|c|c|}
\hline TIPO DE VíNCULO & 1999 & 2000 & 2001 & 2002 & 2003 & 2004 & 2005 & 2006 & 2007 \\
\hline Temporários & 27,2 & 16,8 & 14,0 & 12,6 & 10,9 & 9,8 & 8,5 & 7,6 & 6,1 \\
\hline CLT & 39,3 & 48,0 & 49,8 & 49,6 & 48,7 & 49,3 & 50,6 & 51,0 & 52,1 \\
\hline Outros & 1,4 & 1,7 & 2,5 & 2,4 & 2,5 & 2,8 & 3,0 & 3,2 & 3,3 \\
\hline Fora da RAIS & 32,1 & 33,6 & 33,7 & 35,4 & 37,9 & 38,2 & 37,9 & 38,2 & 38,4 \\
\hline Total & 100,0 & 100,0 & 100,0 & 100,0 & 100,0 & 100,0 & 100,0 & 100,0 & 100,0 \\
\hline
\end{tabular}

Fonte: Ministério do Trabalho e do Emprego. Painel RAIS-Migra, corte especial para a Região Metropolitana de São Paulo, Período 1998-2007 (processamento próprio).

Assim, embora no final do período outros 38,4\% tenham saído dos registros da RAIS (e provavelmente tenham retornado ao mercado informal), a característica mais marcante dos temporários era a migração para outros setores da economia, notadamente na indústria e no comércio. Em termos relativos, num período de nove anos, apenas 16,8\% deles mantinham-se ocupados como empregados das agências (Tabela III.8).

TABELA III. 8: Percurso dos temporários que em 1998 estavam ocupados nos serviços de seleção, agenciamento e locação de mão-de-obra.

\begin{tabular}{|l|r|r|r|r|r|r|r|r|r|}
\hline SEÇÕES CNAE & 1999 & 2000 & 2001 & 2002 & 2003 & 2004 & 2005 & 2006 & 2007 \\
\hline $\begin{array}{l}\text { Seleção, Agenciamento e } \\
\text { Locação }\end{array}$ & 36,4 & 27,6 & 24,9 & 23,5 & 21,4 & 20,1 & 19,0 & 18,2 & 16,8 \\
\hline $\begin{array}{l}\text { Indústria de } \\
\text { transformação }\end{array}$ & 11,8 & 15,2 & 15,9 & 15,0 & 14,7 & 15,3 & 15,5 & 15,6 & 15,7 \\
\hline Comércio & 8,0 & 9,4 & 9,7 & 9,6 & 9,6 & 9,6 & 9,8 & 9,5 & 9,7 \\
\hline Construção & 4,5 & 4,7 & 4,7 & 4,5 & 4,1 & 3,9 & 4,0 & 4,2 & 4,6 \\
\hline $\begin{array}{l}\text { Transporte, } \\
\text { armazenagem }\end{array}$ & 2,0 & 2,7 & 3,0 & 3,1 & 3,1 & 3,4 & 3,6 & 3,8 & 4,0 \\
\hline Bancos e finanças & 0,6 & 0,8 & 1,0 & 1,0 & 1,0 & 1,0 & 1,1 & 1,2 & 1,2 \\
\hline $\begin{array}{l}\text { Alojamento e } \\
\text { alimentação }\end{array}$ & 1,4 & 1,5 & 1,6 & 1,5 & 1,5 & 1,5 & 1,5 & 1,5 & 1,5 \\
\hline Administração Pública & 0,6 & 1,0 & 1,4 & 1,9 & 2,1 & 2,3 & 2,5 & 2,7 & 2,9 \\
\hline Outras seções da CNAE & 2,7 & 3,6 & 4,0 & 4,4 & 4,6 & 4,7 & 5,0 & 5,2 & 5,2 \\
\hline Fora da RAIS & 32,1 & 33,6 & 33,7 & 35,4 & 37,9 & 38,2 & 37,9 & 38,2 & 38,4 \\
\hline Total & 100,0 & 100,0 & 100,0 & 100,0 & 100,0 & 100,0 & 100,0 & 100,0 & 100,0 \\
\hline
\end{tabular}

Período 1998-2007(processamento próprio).

Tal migração parece, de resto, coerente com a ocupação na qual os indivíduos estavam alocados em 1998 (Tabela III.9), o que provavelmente explica a possibilidade de mudança na sua condição contratual. 
TABELA III. 9: Distribuição dos empregados das agências em 1998, segundo as ocupações.

\begin{tabular}{|c|c|c|}
\hline Grande Grupo Ocupacional (baseado na CBO-1998) & $\mathbf{N}$ & $\%$ \\
\hline $\begin{array}{l}\text { Trabalhadores da Produção Industrial, Operadores de } \\
\text { máquinas, Condutores de veículos e assemelhados }\end{array}$ & 80.519 & 48,3 \\
\hline Trabalhadores dos Serviços Administrativos & 44.345 & 26,6 \\
\hline Trabalhadores do Turismo, Hospedaria, Segurança e Saúde & 19.137 & 11,5 \\
\hline Trabalhadores do Comércio & 18.250 & 11,0 \\
\hline Trabalhadores das profissões científicas, técnicas e artísticas & 3.174 & 1,9 \\
\hline Membros do Poder Executivo, Legislativo e Judiciário & 575 & 0,4 \\
\hline Trabalhadores Agropecuários, Florestais e da Pesca & 283 & 0,2 \\
\hline Sem informação & 288 & 0,2 \\
\hline Total & 166.571 & 100,0 \\
\hline
\end{tabular}

No caso dos terceirizados (CLT) essa migração também acontece; no entanto, tanto a transição a outros setores quanto a saída do mercado formal ocorrem num ritmo mais lento. Enquanto, no caso dos temporários, mais de 30\% dos trabalhadores já se retiravam do mercado formal ainda no final do primeiro ano, no caso dos terceirizados, a saída do mercado formal só atingia a marca dos três dígitos ao final do quarto ano (Tabela III.10).

TABELA III. 10: Percurso dos terceirizados ( $N=46.632)$ que em 1998 estavam ocupados nos serviços de seleção, agenciamento e locação de mão-de-obra.

\begin{tabular}{|l|r|r|r|r|r|r|r|r|r|}
\hline SEÇÕES CNAE & 1999 & 2000 & 2001 & 2002 & 2003 & 2004 & 2005 & 2006 & 2007 \\
\hline $\begin{array}{l}\text { Seleção, Agenciamento } \\
\text { e Locação }\end{array}$ & 61,4 & 46,5 & 38,8 & 35,0 & 31,5 & 29,2 & 27,4 & 25,9 & 24,8 \\
\hline $\begin{array}{l}\text { Indústria de } \\
\text { transformação }\end{array}$ & 5,2 & 8,0 & 9,2 & 9,3 & 9,4 & 9,9 & 10,4 & 10,9 & 11,0 \\
\hline Comércio & 4,2 & 6,3 & 7,7 & 7,9 & 8,4 & 8,6 & 9,1 & 9,0 & 9,2 \\
\hline Bancos e finanças & 3,2 & 3,1 & 2,7 & 2,6 & 2,4 & 2,3 & 2,4 & 2,6 & 2,7 \\
\hline Construção & 2,7 & 3,5 & 3,9 & 3,6 & 3,6 & 3,5 & 3,6 & 3,6 & 4,0 \\
\hline $\begin{array}{l}\text { Transporte, } \\
\text { armazenagem }\end{array}$ & 1,5 & 2,5 & 4,0 & 3,9 & 4,0 & 4,1 & 4,3 & 4,5 & 4,5 \\
\hline Adm. Pública & 0,6 & 1,3 & 1,8 & 2,2 & 2,4 & 2,6 & 2,8 & 3,0 & 3,1 \\
\hline $\begin{array}{l}\text { Alojamento e } \\
\text { alimentação }\end{array}$ & 0,6 & 0,8 & 1,0 & 1,1 & 1,1 & 1,1 & 1,2 & 1,2 & 1,3 \\
\hline Outras seções da CNAE & 2,4 & 3,6 & 4,2 & 4,7 & 5,0 & 5,4 & 5,8 & 5,9 & 6,0 \\
\hline Fora da RAIS & 18,1 & 24,2 & 26,8 & 29,6 & 32,3 & 33,2 & 33,1 & 33,4 & 33,5 \\
\hline Total & 100,0 & 100,0 & 100,0 & 100,0 & 100,0 & 100,0 & 100,0 & 100,0 & 100,0 \\
\hline
\end{tabular}

Fonte: Ministério do Trabalho e do Emprego. Painel RAIS-Migra, corte especial para a Região Metropolitana de São Paulo, Período 1998-2007(processamento próprio).

Essas primeiras evidências apontam para a plausibilidade da nossa hipótese de que as agências facilitavam as trocas de empregos e das condições contratuais, sendo, 
assim, um importante acesso a firmas que provavelmente pagariam salários superiores e confeririam, a esses trabalhadores, maiores benefícios extra-salariais.

Contudo, sua utilidade se restringia a uma parcela muito especifica da mão-deobra. Como notado em outras realidades, por aqui as agências também realizavam uma cuidadosa triagem na qual selecionavam principalmente indivíduos que, apesar de desempregados, já tinham uma trajetória de trabalho anterior ou alguma experiência prévia de trabalho formal, sendo muito poucos aqueles que se beneficiavam sem nunca terem trabalhado antes.

Nesse sentido, os dados sobre a trajetória retrospectiva dos empregados das empresas de seleção, agenciamento e locação de mão-de-obra são especialmente esclarecedores. Em 2007, de um total de 407.481 indivíduos ocupados (seja como temporário, seja como terceirizado), 42,6\% já estavam trabalhando há mais de um ano em empregos obtidos através das agências; o outro grupo também significativo contabilizava mais de $30 \%$ dos indivíduos e era composto por aqueles que estavam no mercado informal, fora dos registros da RAIS.

TABELA III. 11: De onde provêm os trabalhadores das empresas de locação, agenciamento e seleção?(RMSP: painel retrospectivo dos ocupados em 2007 acompanhados desde 2000).

\begin{tabular}{|l|c|c|c|c|c|c|c|}
\hline SEÇÕES CNAE & $\mathbf{2 0 0 6}$ & $\mathbf{2 0 0 5}$ & $\mathbf{2 0 0 4}$ & $\mathbf{2 0 0 3}$ & $\mathbf{2 0 0 2}$ & $\mathbf{2 0 0 1}$ & $\mathbf{2 0 0 0}$ \\
\hline $\begin{array}{l}\text { Seleção Agenciamento e } \\
\text { Locação }\end{array}$ & $\mathbf{4 2 , 6}$ & $\mathbf{2 9 , 2}$ & $\mathbf{2 3 , 0}$ & $\mathbf{1 9 , 2}$ & $\mathbf{1 6 , 9}$ & $\mathbf{1 4 , 5}$ & $\mathbf{1 2 , 4}$ \\
\hline Comércio & 9,2 & 10,1 & 9,4 & 8,6 & 7,9 & 7,1 & 6,1 \\
\hline Indústria de Transformação & 6,6 & 7,3 & 7,0 & 6,3 & 6,2 & 6,1 & 5,7 \\
\hline Construção & 1,8 & 1,8 & 1,9 & 1,9 & 2,1 & 2,1 & 2,0 \\
\hline Transporte & 1,7 & 1,9 & 1,8 & 1,6 & 1,6 & 1,5 & 1,3 \\
\hline Alojamento e alimentação & 1,6 & 1,6 & 1,5 & 1,3 & 1,3 & 1,2 & 1,1 \\
\hline Bancos e finanças & 0,4 & 0,4 & 0,4 & 0,4 & 0,4 & 0,4 & 0,4 \\
\hline Adm Pública & 0,5 & 0,7 & 0,7 & 0,7 & 0,6 & 0,5 & 0,4 \\
\hline Outras seções da CNAE & 2,6 & 3,2 & 3,0 & 2,9 & 2,8 & 2,6 & 2,4 \\
\hline Fora da RAIS & $\mathbf{3 3 , 0}$ & $\mathbf{4 3 , 8}$ & $\mathbf{5 1 , 4}$ & $\mathbf{5 7 , 2}$ & $\mathbf{6 0 , 2}$ & $\mathbf{6 4 , 1}$ & $\mathbf{6 8 , 2}$ \\
\hline Total & 100,0 & 100,0 & 100,0 & 100,0 & 100,0 & 100,0 & 100,0 \\
\hline
\end{tabular}

Fonte: Ministério do Trabalho e do Emprego. Painel RAIS-Migra, corte especial para a Região Metropolitana de São Paulo, Período 2000-2007(processamento próprio).

Embora muitos já circulassem pelo setor da intermediação, a maior parte deles era alocada por agências diferentes. Segundo as informações sobre o tipo de admissão, é possível verificar que apenas 19,3\% tinham seu vínculo com a agência atual firmado no ano anterior (Tabela III.12). 
TABELA III. 12: Tipo de admissão dos trabalhadores ocupados nas empresas de seleção, agenciamento e locação de mão-de-obra (RMSP: painel retrospectivo dos ocupados em 2007 acompanhados desde 2000).

\begin{tabular}{|l|c|c|c|c|c|c|c|c|}
\hline TIPO DE ADMISSÃO & 2007 & 2006 & 2005 & 2004 & 2003 & 2002 & 2001 & 2000 \\
\hline Reemprego & 73,7 & $\mathbf{3 4 , 9}$ & 25,8 & 21,5 & 17,5 & 16,6 & 14,7 & 13,0 \\
\hline Admitido anteriormente & $\mathbf{1 9 , 3}$ & 25,3 & 24,2 & 21,6 & 20,9 & 18,9 & 17,3 & 15,2 \\
\hline Primeiro emprego & 6,0 & 5,7 & 5,1 & 4,5 & 3,6 & 3,6 & 3,4 & 3,0 \\
\hline Outros & 1,0 & 1,1 & 1,0 & 0,9 & 0,8 & 0,8 & 0,6 & 0,5 \\
\hline Fora da RAIS & 0,0 & 33,0 & 43,8 & 51,4 & 57,2 & 60,2 & 64,1 & 68,2 \\
\hline Total & 100,0 & 100,0 & 100,0 & 100,0 & 100,0 & 100,0 & 100,0 & 100,0 \\
\hline
\end{tabular}

Fonte: Ministério do Trabalho e do Emprego. Painel RAIS-Migra, corte especial para a Região Metropolitana de São Paulo, Período 2000-2007(processamento próprio).

Ademais, cerca de 35\% tinham mais de um evento ocupacional antes da passagem pelas agências e quase a metade (49,5\%) provinha de contratos CLT por tempo indeterminado (Tabela III.13).

TABELA III. 13: Vínculo de trabalho anterior à passagem pelo setor de seleção, agenciamento e locação de mão-de-obra (RMSP: painel retrospectivo dos ocupados em 2007 acompanhados desde 2000).

\begin{tabular}{|l|r|r|r|r|r|r|r|r|}
\hline $\begin{array}{c}\text { TIPO DE } \\
\text { VíNCULO }\end{array}$ & 2007 & 2006 & 2005 & 2004 & 2003 & 2002 & 2001 & 2000 \\
\hline Temporário & 60,7 & 15,2 & 9,0 & 7,2 & 5,8 & 5,3 & 4,3 & 3,8 \\
\hline CLT & 38,7 & 49,5 & 45,7 & 40,0 & 35,9 & 33,4 & 30,6 & 27,3 \\
\hline Outros & 0,6 & 2,2 & 1,5 & 1,3 & 1,1 & 1,0 & 1,0 & 0,7 \\
\hline Fora da RAIS & 0,0 & 33,0 & 43,8 & 51,4 & 57,2 & 60,2 & 64,1 & 68,2 \\
\hline Total & 100,0 & 100,0 & 100,0 & 100,0 & 100,0 & 100,0 & 100,0 & 100,0 \\
\hline
\end{tabular}

Fonte: Ministério do Trabalho e do Emprego. Painel RAIS-Migra, corte especial para a Região Metropolitana de São Paulo, Período 2000-2007(processamento próprio).

Cotejando o desempenho dos temporários alocados pelas agências com o dos temporários contratados diretamente pela indústria da transformação (os quais, em 1998, contabilizavam somente 878 casos), fica ainda mais evidente o papel das agências enquanto (re)localizadoras ou (re)orientadoras dos indivíduos no mercado formal (Tabela III.14). Ou seja, verifica-se que a proporção e o ritmo da migração a outros setores é bem menor entre os temporários da indústria. 
TABELA III. 14: Percurso dos temporários que em 1998 foram contratados diretamente pelas indústrias de transformação.

\begin{tabular}{|l|r|r|r|r|r|r|r|r|r|}
\hline SEÇÕES CNAE & 1999 & 2000 & 2001 & 2002 & 2003 & 2004 & 2005 & 2006 & 2007 \\
\hline $\begin{array}{l}\text { Indústria de } \\
\text { transformação }\end{array}$ & 78,8 & 77,7 & 75,3 & 70,7 & 68,1 & 62,8 & 60,6 & 62,1 & 55,8 \\
\hline $\begin{array}{l}\text { Seleção, Agenciamento e } \\
\text { Locação }\end{array}$ & 6,2 & 4,8 & 4,7 & 5,9 & 4,7 & 5,0 & 4,7 & 5,8 & 6,3 \\
\hline Comércio & 1,9 & 3,1 & 3,6 & 4,4 & 4,1 & 4,6 & 4,6 & 4,7 & 6,0 \\
\hline Outras seções da CNAE & 3,3 & 3,4 & 3,5 & 3,5 & 4,7 & 5,6 & 9,3 & 7,1 & 7,3 \\
\hline Fora da RAIS & 9,8 & 11,0 & 12,9 & 15,4 & 18,5 & 22,1 & 20,8 & 20,4 & 24,6 \\
\hline Total & 100,0 & 100,0 & 100,0 & 100,0 & 100,0 & 100,0 & 100,0 & 100,0 & 100,0 \\
\hline
\end{tabular}

Fonte: Ministério do Trabalho e do Emprego. Painel RAIS-Migra, corte especial para a Região Metropolitana de São Paulo, Período 1998-2007(processamento próprio).

Esses trabalhadores também parecem mais protegidos contra a informalidade; efeito, esse, que reflete muito mais a preservação no interior do setor industrial do que a transição aos contratos CLT. Assim, embora quase $80 \%$ dos temporários permaneçam na indústria, menos da metade deles $(41,5 \%)$ tornam-se empregados permanentes ao final do primeiro ano (TABELA III.15). Isso significa que o tempo necessário para a efetivação de um temporário pode ser superior há dois anos.

TABELA III. 15: Vínculos subseqüentes dos temporários que em 1998 foram contratados diretamente pelas indústrias de transformação.

\begin{tabular}{|l|c|c|c|c|c|c|c|c|c|}
\hline $\begin{array}{c}\text { TIPO DE } \\
\text { VíNCULO }\end{array}$ & 1999 & 2000 & 2001 & 2002 & 2003 & 2004 & 2005 & 2006 & 2007 \\
\hline CLT & $\mathbf{4 1 , 5}$ & $\mathbf{5 0 , 7}$ & 67,4 & 68,3 & 65,8 & 60,4 & 63,8 & 64,0 & 60,7 \\
\hline Temporários & $\mathbf{4 7 , 3}$ & $\mathbf{3 7 , 8}$ & 18,2 & 15,1 & 14,2 & 15,1 & 13,2 & 13,3 & 12,6 \\
\hline Outros & 1,5 & 0,5 & 1,5 & 1,1 & 1,5 & 2,4 & 2,2 & 2,3 & 2,1 \\
\hline Fora da RAIS & 9,8 & 11,0 & 12,9 & 15,4 & 18,5 & 22,1 & 20,8 & 20,4 & 24,6 \\
\hline Total & 100,0 & 100,0 & 100,0 & 100,0 & 100,0 & 100,0 & 100,0 & 100,0 & 100,0 \\
\hline
\end{tabular}

Fonte: Ministério do Trabalho e do Emprego. Painel RAIS-Migra, corte especial para a Região Metropolitana de São Paulo, Período 1998-2007(processamento próprio).

Essa intensa troca de setores e de situações contratuais seria uma característica típica dos empregados das agências? Ou refere-se a uma característica mais ampla, comum aos trabalhadores ocupados nas atividades-meios, freqüentemente executadas por empresas terceiras? Na próxima seção, investigo os vínculos de trabalho e o percurso ocupacional dos trabalhadores ocupados em outros setores de serviços; entre eles, destacam-se os empregados na limpeza e na vigilância, tendo em vista uma possível avaliação dos resultados obtidos até agora. 


\section{III - Os empregados das agências vis-à-vis os trabalhadores dos serviços auxiliares.}

Acompanhando, em primeiro lugar, a coorte dos trabalhadores que em 1998 estavam ocupados no setor dos serviços prestados principalmente às empresas (CNAE=74993), nota-se que os percursos ocupacionais assemelham-se bastante aos percursos dos terceirizados alocados pelas agências (rever, Tabela III.10), sendo marcante a semelhança no ritmo, mais lento, da migração (Tabela III.16).

TABELA III. 16: Percurso dos trabalhadores que em 1998 estavam ocupados nos serviços prestados principalmente às empresas $(\mathrm{N}=191.545)$.

\begin{tabular}{l|l|c|c|c|c|c|c|c|c|c|}
\hline SEÇÕES CNAE & 1999 & 2000 & 2001 & 2002 & 2003 & 2004 & 2005 & 2006 & 2007 \\
\hline Serviços p/ empresas & 68,4 & 51,8 & 44,9 & 39,1 & 35,4 & 32,2 & 30,5 & 28,3 & 27,1 \\
\hline Indústria de transformação & 3,6 & 5,9 & 7,3 & 7,7 & 8,0 & 8,5 & 8,9 & 9,3 & 9,4 \\
\hline Comércio & 3,5 & 6,1 & 7,1 & 7,6 & 7,8 & 8,2 & 8,5 & 8,6 & 8,8 \\
\hline $\begin{array}{l}\text { Transporte e } \\
\text { armazenagem }\end{array}$ & 1,8 & 3,3 & 3,9 & 4,1 & 3,9 & 4,2 & 4,4 & 4,7 & 4,9 \\
\hline Construção & 1,7 & 2,3 & 2,4 & 2,3 & 2,2 & 2,2 & 2,3 & 2,5 & 2,7 \\
\hline Bancos e finanças & 1,2 & 1,5 & 2,2 & 2,2 & 2,3 & 2,6 & 2,4 & 2,9 & 2,9 \\
\hline Alojamento e alimentação & 0,9 & 1,8 & 1,6 & 1,7 & 1,6 & 1,7 & 1,7 & 1,6 & 1,7 \\
\hline Adm Pública & 0,7 & 1,0 & 0,9 & 1,2 & 1,4 & 1,9 & 2,1 & 2,2 & 2,3 \\
\hline Outras CNAEs & 2,0 & 3,2 & 3,7 & 4,2 & 4,5 & 4,7 & 5,0 & 5,3 & 5,4 \\
\hline Fora da RAIS & 16,3 & 23,2 & 26,1 & 29,9 & 32,7 & 33,9 & 34,2 & 34,6 & 34,8 \\
\hline Total & 100,0 & 100,0 & 100,0 & 100,0 & 100,0 & 100,0 & 100,0 & 100,0 & 100,0 \\
\hline
\end{tabular}

Ademais, há uma nítida predominância dos contratos CLT - ou seja, dos contratos, a princípio, sem limites de duração - que indica a capacidade de cerca de $60 \%$ dos trabalhadores manterem-se no mercado formal e, em grande parte, explica a redução no ritmo das transições (Tabela III.17).

TABELA III. 17: Tipos de vínculos dos trabalhadores que em 1998 estavam ocupados nos serviços prestados principalmente às empresas.

\begin{tabular}{|l|r|r|r|r|r|r|r|r|r|r|}
\hline $\begin{array}{l}\text { TIPO DE } \\
\text { VíNCULO }\end{array}$ & 1998 & 1999 & 2000 & 2001 & 2002 & 2003 & 2004 & 2005 & 2006 & 2007 \\
\hline CLT & $\mathbf{9 6 , 5}$ & $\mathbf{8 0 , 6}$ & $\mathbf{7 3 , 6}$ & $\mathbf{7 0 , 0}$ & $\mathbf{6 6 , 4}$ & $\mathbf{6 3 , 8}$ & $\mathbf{6 2 , 5}$ & $\mathbf{6 2 , 3}$ & $\mathbf{6 1 , 8}$ & $\mathbf{6 1 , 7}$ \\
\hline Temporários & 2,8 & 2,2 & 2,1 & 1,9 & 1,9 & 1,5 & 1,4 & 1,3 & 1,1 & 1,0 \\
\hline Outros & 0,6 & 0,8 & 1,1 & 2,0 & 1,8 & 1,9 & 2,1 & 2,3 & 2,4 & 2,5 \\
\hline Fora da RAIS & $\mathbf{0 , 1}$ & $\mathbf{1 6 , 3}$ & $\mathbf{2 3 , 2}$ & $\mathbf{2 6 , 1}$ & $\mathbf{2 9 , 9}$ & $\mathbf{3 2 , 8}$ & $\mathbf{3 3 , 9}$ & $\mathbf{3 4 , 2}$ & $\mathbf{3 4 , 7}$ & $\mathbf{3 4 , 8}$ \\
\hline Total & 100,0 & 100,0 & 100,0 & 100,0 & 100,0 & 100,0 & 100,0 & 100,0 & 100,0 & 100,0 \\
\hline
\end{tabular}

Fonte: Ministério do Trabalho e do Emprego. Painel RAIS-Migra, corte especial para a Região Metropolitana de São

Paulo, Período 1998-2007(processamento próprio). 
Essa tendência, tanto à baixa transição quanto ao predomínio dos contratos CLT, parece ser uma característica comum aos setores de serviços em geral. Observando, o desempenho dos empregados das empresas de limpeza e higienização, chama a atenção que quase seis em cada dez indivíduos também permaneciam empregados via contratos CLT (Tabela III. 18).

TABELA III. 18: Tipos de vínculos dos trabalhadores que em 1998 estavam ocupados nos serviços de limpeza e higienização ( $N=172.273)$.

\begin{tabular}{|l|r|r|r|r|r|r|r|r|r|r|}
\hline $\begin{array}{l}\text { TIPO DE } \\
\text { VíNCULO }\end{array}$ & 1998 & 1999 & 2000 & 2001 & 2002 & 2003 & 2004 & 2005 & 2006 & 2007 \\
\hline CLT & $\mathbf{9 9 , 3}$ & $\mathbf{8 1 , 1}$ & $\mathbf{7 3 , 2}$ & $\mathbf{6 9 , 2}$ & $\mathbf{6 5 , 6}$ & $\mathbf{6 2 , 8}$ & $\mathbf{6 0 , 9}$ & $\mathbf{6 0 , 1}$ & $\mathbf{5 9 , 5}$ & $\mathbf{5 9 , 3}$ \\
\hline Temporário & 0,1 & 0,8 & 1,0 & 0,9 & 0,9 & 0,8 & 0,7 & 0,7 & 0,6 & 0,6 \\
\hline Outros & 0,3 & 0,5 & 0,7 & 1,0 & 1,0 & 1,1 & 1,2 & 1,3 & 1,4 & 1,5 \\
\hline Fora da RAIS & 0,3 & 17,6 & 25,2 & 28,9 & 32,5 & 35,4 & 37,2 & 37,9 & 38,5 & 38,7 \\
\hline Total & 100,0 & 100,0 & 100,0 & 100,0 & 100,0 & 100,0 & 100,0 & 100,0 & 100,0 & 100,0 \\
\hline
\end{tabular}

Fonte: Ministério do Trabalho e do Emprego. Painel RAIS-Migra, corte especial para a Região Metropolitana de São Paulo, Período 1998-2007(processamento próprio).

No entanto, igualmente significativo era a polarização existente entre os percursos. Assim, em todos os anos, o movimento de permanência no setor ou de saída em direção ao mercado informal explicava a trajetória de cerca de $80 \%$ dos indivíduos ocupados nos serviços de limpeza e higienização (Tabela III.19).

TABELA III. 19: Percurso dos trabalhadores que em 1998 estavam ocupados nos serviços de limpeza e higienização.

\begin{tabular}{|l|r|r|r|r|r|r|r|r|r|}
\hline SEÇÕES CNAE & 1999 & 2000 & 2001 & 2002 & 2003 & 2004 & 2005 & 2006 & 2007 \\
\hline Limpeza e higienização & $\mathbf{7 6 , 2}$ & $\mathbf{6 4 , 1}$ & $\mathbf{5 7 , 7}$ & $\mathbf{5 3 , 1}$ & $\mathbf{4 9 , 4}$ & $\mathbf{4 6 , 6}$ & $\mathbf{4 4 , 9}$ & $\mathbf{4 3 , 5}$ & $\mathbf{4 2 , 4}$ \\
\hline Comércio & 1,5 & 2,6 & 3,2 & 3,4 & 3,7 & 3,8 & 4,1 & 4,1 & 4,4 \\
\hline $\begin{array}{l}\text { Indústria de } \\
\text { Transformação }\end{array}$ & 1,3 & 2,4 & 3,0 & 3,2 & 3,3 & 3,7 & 3,8 & 4,0 & 4,2 \\
\hline Construção & 1,2 & 1,8 & 1,9 & 1,7 & 1,6 & 1,7 & 1,7 & 1,8 & 2,0 \\
\hline Limpeza urbana & 0,6 & 0,9 & 1,1 & 1,3 & 1,4 & 1,5 & 1,5 & 1,5 & 1,5 \\
\hline Outras seções da CNAE & 1,8 & 3,3 & 4,5 & 5,1 & 5,5 & 5,8 & 6,3 & 6,8 & 7,2 \\
\hline Fora da RAIS & $\mathbf{1 7 , 3}$ & $\mathbf{2 4 , 9}$ & $\mathbf{2 8 , 6}$ & $\mathbf{3 2 , 2}$ & $\mathbf{3 5 , 1}$ & $\mathbf{3 6 , 9}$ & $\mathbf{3 7 , 7}$ & $\mathbf{3 8 , 2}$ & $\mathbf{3 8 , 4}$ \\
\hline Total & 100,0 & 100,0 & 100,0 & 100,0 & 100,0 & 100,0 & 100,0 & 100,0 & 100,0 \\
\hline
\end{tabular}

Fonte: Ministério do Trabalho e do Emprego. Painel RAIS-Migra, corte especial para a Região Metropolitana de São Paulo, Período 1998-2007(processamento próprio).

É certo que, comparados aos trabalhadores ocupados em setores mais tradicionais da economia, como na indústria ou nos bancos, os trabalhadores das agências e dos serviços de limpeza estavam, muitas vezes, mais expostos à informalidade. No entanto, a informalidade entre eles não destoava muito da 
informalidade encontrada no conjunto dos trabalhadores subcontratados. Assim, num período de nove anos, quase $40 \%$ dos trabalhadores saíam da RAIS independentemente do serviço estudado.

A única exceção parecia ser encontrada entre os empregados das empresas de investigação, vigilância e segurança. Entre eles o ritmo das trocas de setor era menor e a saída dos registros da RAIS caía para quase um quarto ao longo do período (Tabela III.20).

TABELA III. 20: Percurso dos trabalhadores que em 1998 estavam ocupados nas atividades de investigação, vigilância e segurança $(\mathrm{N}=81552)$.

\begin{tabular}{|l|r|r|r|r|r|r|r|r|r|}
\hline SEÇÕES CNAE & 1999 & 2000 & 2001 & 2002 & 2003 & 2004 & 2005 & 2006 & 2007 \\
\hline $\begin{array}{l}\text { Vigilância e } \\
\text { segurança }\end{array}$ & 87,4 & 78,9 & 72,8 & 67,3 & 63,4 & 59,9 & 57,9 & 55,2 & 53,4 \\
\hline Comércio & 1,2 & 2,2 & 2,9 & 3,5 & 3,7 & 4,0 & 4,3 & 4,6 & 4,8 \\
\hline $\begin{array}{l}\text { Indústria de } \\
\text { Transformação }\end{array}$ & 1,2 & 2,1 & 2,7 & 3,1 & 3,4 & 3,8 & 4,1 & 4,4 & 4,6 \\
\hline Construção & 0,6 & 0,9 & 1,1 & 1,2 & 1,2 & 1,3 & 1,3 & 1,6 & 1,8 \\
\hline $\begin{array}{l}\text { Outras seções da } \\
\text { CNAE }\end{array}$ & 2,3 & 4,2 & 5,9 & 6,9 & 7,2 & 8,0 & 8,8 & 9,3 & 9,8 \\
\hline Fora da RAIS & 7,4 & 11,6 & 14,6 & 18,1 & 21,0 & 22,9 & 23,6 & 25,0 & 25,6 \\
\hline Total & 100,0 & 100,0 & 100,0 & 100,0 & 100,0 & 100,0 & 100,0 & 100,0 & 100,0 \\
\hline
\end{tabular}

Fonte: Ministério do Trabalho e do Emprego. Painel RAIS-Migra, corte especial para a Região Metropolitana de São Paulo, Período 1998-2007(processamento próprio).

Contudo, a permanência no setor não significava ausência de transições entre diferentes empregos e ocupações; pelo contrário, esses trabalhadores eram também os que apresentavam as médias mais altas de admissões e ocupações exercidas no período. Ou seja, eles transitavam em diferentes ocupações, mesmo quando empregados num mesmo ramo de atividade (Tabela III.21).

TABELA III. 21: Número médio da quantidade de admissões, desligamentos e ocupações exercidas entre 1998 e 2007.

\begin{tabular}{|l|c|c|c|}
\hline SETORES EM 1998 & $\begin{array}{c}\text { Quantidade de } \\
\text { admissões }\end{array}$ & $\begin{array}{c}\text { Quantidade de } \\
\text { desligamentos }\end{array}$ & $\begin{array}{c}\text { Quantidade de } \\
\text { ocupações }\end{array}$ \\
\hline $\begin{array}{l}\text { Trabalhadores dos serviços de } \\
\text { vigilância e segurança }\end{array}$ & 8,2 & 7,5 & 9,0 \\
\hline $\begin{array}{l}\text { Trabalhadores dos serviços de } \\
\text { seleção, agenciamento e locação }\end{array}$ & 8,2 & 7,7 & 8,2 \\
\hline $\begin{array}{l}\text { Trabalhadores dos serviços } \\
\text { prestados principalmente às } \\
\text { empresas }\end{array}$ & 6,1 & 5,6 & 7,2 \\
\hline $\begin{array}{l}\text { Trabalhadores dos serviços limpeza } \\
\text { e higienização }\end{array}$ & 4,7 & 4,2 & 4,9 \\
\hline
\end{tabular}

Fonte: Ministério do Trabalho e do Emprego. Painel RAIS-Migra, corte especial para a Região Metropolitana de São Paulo, Período 1998-2007(processamento próprio). 
Ademais, a quase totalidade de seus empregados era do sexo masculino, sendo essa a distribuição mais desigual encontrada entre todos os trabalhadores dos serviços (Tabela III.22).

TABELA III. 22: Distribuição sexual dos trabalhadores ocupados nos serviços auxiliares em 1998.

\begin{tabular}{|l|c|c|}
\hline SETORES & Masculino & Feminino \\
\hline Vigilância e segurança & 93,4 & 6,6 \\
\hline Seleção, Agenciamento e Locação & 61,6 & 38,4 \\
\hline Serviços prestados às empresas & 60,3 & 39,7 \\
\hline Limpeza e higienização & 37,9 & 62,1 \\
\hline
\end{tabular}

Fonte: Ministério do Trabalho e do Emprego. Painel RAIS-Migra, corte especial para a Região Metropolitana de São Paulo, Período 1998-2007(processamento próprio).

Tal homogeneidade, somada às barreiras de entrada existentes no setor ${ }^{61}$, parecia resultar na predominância dos contratos CLT. Assim, sete em cada dez indivíduos mantinham-se continuamente contratados sob regime celetista (Tabela III.23); mais uma característica específica, que reforçava nossa hipótese de que os empregados das empresas de investigação, vigilância e segurança, eram uma exceção em relação ao conjunto dos trabalhadores subcontratados.

TABELA III. 23: Tipo de vínculo dos trabalhadores que em 1998 estavam ocupados nas atividades de investigação, vigilância e segurança.

\begin{tabular}{|l|r|r|r|r|r|r|r|r|r|r|}
\hline $\begin{array}{l}\text { TIPO DE } \\
\text { VíNCULO }\end{array}$ & 1998 & 1999 & 2000 & 2001 & 2002 & 2003 & 2004 & 2005 & 2006 & 2007 \\
\hline CLT & 99,9 & 91,5 & 86,5 & 82,6 & 79,0 & 76,2 & 74,1 & 73,3 & 71,9 & 71,0 \\
\hline Temporário & 0,0 & 0,6 & 1,0 & 0,8 & 0,8 & 0,8 & 0,8 & 0,7 & 0,6 & 0,4 \\
\hline Outros & 0,1 & 0,6 & 0,8 & 2,0 & 2,0 & 2,0 & 2,3 & 2,4 & 2,6 & 2,9 \\
\hline Fora da RAIS & 0,0 & 7,4 & 11,7 & 14,6 & 18,1 & 21,1 & 22,9 & 23,6 & 25,0 & 25,6 \\
\hline Total & 100,0 & 100,0 & 100,0 & 100,0 & 100,0 & 100,0 & 100,0 & 100,0 & 100,0 & 100,0 \\
\hline
\end{tabular}

Fonte: Ministério do Trabalho e do Emprego. Painel RAIS-Migra, corte especial para a Região Metropolitana de São Paulo, Período 1998-2007(processamento próprio).

Portanto, os empregados das agências não estavam nem mais, nem menos expostos à informalidade do que o restante dos trabalhadores empregados nos serviços auxiliares. Além disso, havia indícios de que o emprego no setor de serviços não prejudicava a trajetória de trabalho futura dos indivíduos, uma vez que a média salarial se elevara em todas as quatro coortes de trabalhadores investigados.

\footnotetext{
${ }^{61}$ Como se sabe, boa parte das ocupações típicas das atividades de investigação, vigilância e segurança exigem curso técnico e porte de arma.
} 
TABELA III. 24: Média dos salários nos dois extremos do percurso profissional, 1998 e 2007.

\begin{tabular}{|l|c|c|}
\hline SETORES EM 1998 & $\begin{array}{c}\text { Média dos Salários em } \\
1998(\mathrm{R} \$)^{*}\end{array}$ & $\begin{array}{c}\text { Média dos Salários em } \\
2007(\mathrm{R} \$)^{* *}\end{array}$ \\
\hline $\begin{array}{l}\text { Trabalhadores dos serviços prestados } \\
\text { principalmente às empresas. }\end{array}$ & 845,00 & $1.216,00$ \\
\hline $\begin{array}{l}\text { Trabalhadores dos serviços de vigilância e } \\
\text { segurança. }\end{array}$ & 741,00 & 934,80 \\
\hline $\begin{array}{l}\text { Trabalhadores das empresas de seleção, } \\
\text { agenciamento e locação. }\end{array}$ & 533,00 & 836,00 \\
\hline $\begin{array}{l}\text { Trabalhadores dos serviços de limpeza e } \\
\text { higienização. }\end{array}$ & 325,00 & 456,00 \\
\hline
\end{tabular}

Fonte: Ministério do Trabalho e do Emprego. Painel RAIS-Migra, corte especial para a Região Metropolitana de São Paulo, Período 1998-2007(processamento próprio).

*Salário Mínimo de R \$130,00.

**Salário Mínimo de R\$380,00.

Esse achado, aliado aos resultados anteriores, permite concluir que as agências são muito mais eficientes na recolocação e reorientação da trajetória de trabalho dos indivíduos do que na promoção de uma primeira oportunidade no mercado de trabalho. Se, por um lado, são incapazes de oferecer empregos duradouros, por outro, facilitam a migração a outros setores da economia e, com isso, mantêm parcela significativa dos trabalhadores no interior do mercado formal.

Dado que, em 2007, a maior parte de seus empregados concentrava-se no comércio e nas atividades auxiliares - ou seja, em ocupações comumente submetidas a enorme pressão salarial e competitiva - essa formalização tornava-se ainda mais importante, pois para muitos elas eram as únicas garantias de proteção e benefícios (Tabela III.25).

TABELA III. 25: Distribuição relativa dos empregados das agências em 2007, segundo as ocupações.

\begin{tabular}{l|c|c}
\hline Grande Grupo Ocupacional (categorias de 2002) & N & \% \\
\hline Trabalhadores dos serviços, vendedores do comércio em lojas e mercados & 146.252 & 35,89 \\
Trabalhadores de serviços administrativos & 87.677 & 21,52 \\
Trabalhadores da produção de bens e serviços industriais & 92.559 & 22,71 \\
Técnicos de nível médio & 41.743 & 10,24 \\
Trabalhadores em serviços de reparação e manutenção & 14.647 & 3,59 \\
Profissionais das ciências e das artes & 7.938 & 1,95 \\
Outras ocupações & 5.067 & 1,24 \\
Ignorado & 11.598 & 2,85 \\
\hline Total & 407.481 & 100 \\
\hline Fonte: Ministério do Trabalho e do Emprego. Painel RAIS-Migra, corte especial para a Região Metropolitana de São Paulo, \\
Período 1998-2007(processamento próprio). & &
\end{tabular}


Assim, tudo isso nos ajuda a compreender porque as agências privadas de trabalho temporário conseguiram se consolidar na cidade de São Paulo e, atualmente, expandem seus serviços aos meios eletrônicos e à internet. Como o que está em jogo é a quantidade e a velocidade das informações, as agências têm se esforçado para promover uma busca rápida e eficiente de trabalho, sem que os indivíduos tenham que deixar o emprego atual ou, até mesmo, sair de casa (Guimarães, 2005; Vieira, 2009).

Mas, à luz dos achados alinhados neste capitulo, podemos concluir que, se as empresas de locação, agenciamento e seleção têm um papel no que concerne à inclusão de indivíduos no mercado de trabalho e têm um impacto, contra-intuitivamente, muitas vezes positivo sobre trajetórias futuras dos indivíduos, tal papel e tal impacto não são incondicionais ou generalizados.

Assim, elas atingem um segmento do mercado de trabalho dotado de um perfil bastante específico, no que concerne ao sexo (masculino), à idade (jovens) e à escolaridade (intermediária). Do mesmo modo, o efeito dessa sua atuação é igualmente circunscrito; ele impacta aqueles que já dispõem de experiência ocupacional anterior e podem, nesse sentido, ser objeto da sua ação dominantemente re-orientadora sobre as trajetórias ocupacionais que venham a perfazer no mercado de trabalho. 


\section{Conclusão}

O EMPREGO INTERMEDIADO POR AGÊNCIAS: FORMA DE PRECARIZAÇÃO OU MECANISMO EFICAZ PARA RETORNO AO MERCADO DE TRABALHO FORMAL?

A partir dos resultados expostos ao longo deste trabalho é possível concluir que as agências protagonizam dois movimentos simultâneos: por um lado, recebem serviços ou trabalhadores antes alocados, de modo direto e permanente, em outros setores da economia; por outro, reinserem os trabalhadores nos antigos setores ou os alocam em outras ocupações e setores da economia formal. Assim, faz sentido a metáfora empregada por Purcell e Koene (2004) de que, ao invés de tubarões, as agências estão mais próximas dos camaleões, à medida que reduzem os custos de procura e, de acordo com as flutuações econômicas e mudanças legislativas, desenvolvem novos produtos e novas ênfases em suas operações.

Embora a análise tenha se centrado em resultados de pesquisas recentes, o fenômeno em questão nunca deixou de se relacionar e ter como pano de fundo fenômenos sociais mais amplos, quase sempre presente nas análises sociológicas clássicas, como a divisão social do trabalho. ${ }^{62}$

Assim, logo no primeiro capítulo, procurei demonstrar que o processo de abertura e estabilidade da economia brasileira, promovidos durante os anos 1990, teve importantes repercussões sob a configuração do mercado de trabalho e sob modo de organização das empresas. Ou seja, apesar do retorno aos fluxos de financiamentos externos, o aumento da oferta das mercadorias importadas e as políticas de recuperação do valor real da moeda reduziram a flexibilidade dos salários reais e a elevação dos preços; o que, por sua vez, elevou os níveis de desemprego e da subcontratação de mãode-obra (Reis e Camargo, 2007).

Foi essa maior exposição à concorrência externa e o aumento no número dos participantes no mercado mundial (principalmente a partir da entrada da China) que levou à crescente especialização das organizações em parte da função total que até então executavam ou à criação de novas especialidades. Por isso, no segundo capítulo,

\footnotetext{
${ }^{62}$ Nesse sentido, o aumento da especialização e da conseqüente externalização das atividades - temas recorrentes ao longo de toda dissertação - foram associados não só ao desejo individual de maximizar as vantagens, mas também à relação proposta por Dürkheim, no longínquo ano de 1893, de que fenômenos semelhantes derivam da "variação no volume [população] e na densidade [freqüência das relações] das sociedades" (Dürkheim, 2008, p. 258). Ou seja, variam em razão do aumento da população e da freqüência dos contatos entre os indivíduos e os grupos sociais.
} 
procurei explorar a crescente importância assumida pelos intermediários privados no interior do processo produtivo e na operação cotidiana do mercado de trabalho.

Em primeiro lugar, verificou-se que a transferência de atividades e a entrega de sua responsabilidade aos empregados de empresas terceiras (entre elas, empresas de intermediação de mão-de-obra) variavam em razão das disputas quanto à governabilidade interna e à eficiência econômica das organizações (Kalleberg, 2000; Kalleberg \& Marsden, 2004). Em seguida, analisou-se o processo pelo qual as agências de trabalho temporário, pioneiras na atividade de intermediação privada, passaram do simples recrutamento e seleção, para a oferta de serviços auxiliares e de apoio à produção. Concluindo, a partir dos achados de Guimarães $(2005 ; 2009$ b) e do discurso de importantes representantes do setor que, no Brasil, a expansão das atividades das agências respondeu tanto às necessidades de empresas e trabalhadores, quanto às necessidades do Estado e seu quadro político-institucional.

Esses resultados, somados aos resultados já apresentados no início da seção, demonstram que as agências operam e se expandem porque a demanda existe, mesmo em mercados de trabalho cuja regulação se mostra, na prática, flexível.

Uma parte dessa demanda foi extensamente coberta por importantes correntes da literatura internacional e nacional que se concentraram nos estudos sobre a repartição dos riscos e redução dos custos associados à mão-de-obra. Para Bauman (2008), a partir da globalização dos mercados financeiros, a tendência ao aumento da contratação de trabalhadores externos e temporários corresponde a uma necessidade das empresas demonstrarem aos investidores que são capazes de sustentar sua produtividade sem elevar substancialmente seu quadro permanente; evitando, assim, os "arriscados" e “custosos" projetos de longo prazo (Bauman, 2008, p. 39).

Para Antunes (2007) as agências e as pequenas empresas de serviços fazem parte de um movimento de precarização do trabalho, pois refletem a "grande demanda por trabalhadores temporários, sem vínculo empregatício, sem registro formalizado" (Antunes, 2007, p. 16) ${ }^{63}$. Entretanto, antes de precarizar a mão-de-obra como um todo,

\footnotetext{
${ }^{63}$ Segundo Mattoso (1999) a precarização atinge tanto as condições, quanto as relações de trabalho. No primeiro caso - ou seja, precarização das condições de trabalho -, trata-se da: "ampliação do trabalho assalariado sem carteira e do trabalho independente (por conta própria). É identificado pelo aumento do trabalho por tempo determinado, sem renda fixa e em tempo parcial. Enfim, pelo que se costuma chamar de bico. Em geral é identificada pela ausência de contribuição a Previdência Social e, portanto, sem direito à aposentadoria" (Mattoso, 1999, p.8). No segundo caso, a precarização das relações de trabalho
} 
Kalleberg (2000) concluiu que as agências são muitas vezes utilizadas para instituir esquemas de compensação e benefícios diferentes entre os empregados internos e permanentes e os empregados externos (Kalleberg, 2000, p. 348).

Esse último achado revela outra dimensão importante para explicar a demanda pelos serviços das agências, a qual se aproxima dos resultados expostos ao longo da dissertação. Ou seja, ao mesmo tempo em que, para um grupo bem específico de indivíduos, as agências forneciam um instrumento de retorno ou re-orientação da carreira no mercado formal; para outra parcela, também minoritária, porém importante, dos empregados permanentes das firmas contratantes, a subcontratação das atividadesmeio estava associada a uma recuperação e aumento de seus ganhos. Nesse sentido, os achados de Magnum (1985) e Houseman (1997) eram esclarecedores, pois ambos verificaram que nos EUA as principais usuárias das agências eram firmas que pagavam os melhores salários aos seus empregados permanentes, quase sempre acima da média local.

É certo que esse fenômeno reflete o fato de que os trabalhadores sobreviventes aos processos de enxugamento, que permaneceram nos quadros internos das firmas, são os mais qualificados, os quais executam as atividades de maiores retornos financeiros. No entanto, também pode refletir a recuperação da competitividade dos negócios. Assim, no Brasil, Mocelin (2009), constatou que, nos setores de telefonia fixa e móvel, o aumento da contratação externa dos serviços de manutenção e rede (setores nos quais a qualidade do emprego formal é muito discutível) também esteve positivamente relacionado ao crescimento do faturamento, dos serviços e da contratação direta de empregados com ensino superior - os quais, só no ano de 2007, contabilizavam $54 \%$ e $42 \%$ da mão-de-obra empregada nos respectivos setores e ganhavam em média salários superiores a cinco salários mínimos (Mocelin, 2009, p.17).

Portanto, se por um lado, é muito difícil afirmar que o uso das agências precariza o mercado de trabalho como um todo, por outro, é também impossível dizer que parte das agências não teve participação no crescimento do emprego sem carteira verificado durante toda a década de $1990^{64}$. Embora, os dados apresentados aqui vão em outra

remete à "ampliação da desregulamentação, dos contratos temporários, de falsas cooperativas de trabalho, de contratos por empresa, ou mesmo unilaterais" (Mattoso, 1999, p.8).

${ }^{64}$ Segundo os dados da Pesquisa Nacional por Amostra de Domicílios (PNAD-IBGE) ao longo da década de 1990, o emprego assalariado sem carteira representou entre $35 \%$ e $45 \%$ do mercado de trabalho 
direção - ou seja, de que o emprego formal mediado pelas agências cresceu num ritmo mais célere do que o emprego formal como um todo - seus empregados não estiveram imunes ao processo de expansão da informalidade que atingiu o mercado de trabalho brasileiro, expresso nos trajetos de expulsão do trabalho formal intermediado.

Chama a atenção, contudo, que seu comportamento apresentou uma tendência no mínimo semelhante à tendência seguida pelas empresas dos demais setores da economia; ou seja, segundo os dados da RAIS, levando-se em conta que o ritmo de crescimento do emprego formal nas agências manteve-se acelerado e constante, o aumento da informalidade, verificado nos registros da Pesquisa Nacional de Amostra em Domicílios (PNAD-IBGE), só pode ter ocorrido nas pequenas e médias agências excluídas dos registros oficiais e cuja estrutura de incentivos das Delegacias Regionais do Trabalho não favorece a fiscalização (Cardoso e Lage, 2005).

Segundo Cardoso e Lage (2005) os mais de 2 mil auditores fiscais do trabalho estão distribuídos, atualmente, em 27 delegacias regionais espalhadas por todo o Brasil. No entanto, como o sistema de remuneração e de prêmios dos fiscais está lastreado no número de trabalhadores atingidos, no número de carteiras de trabalho registradas e na quantidade de recursos do FGTS arrecadados, a fiscalização privilegia as grandes empresas, as quais, segundo os próprios fiscais, são "mais organizadas", possuem "mais funcionários" e têm recursos financeiros para responder às exigências e eventuais autuações. Em resumo, resultam em melhor produtividade e, conseqüentemente, melhores salários para os fiscais encarregados da inspeção (Cardoso e Lage, 2005, p. 471).

Portanto, as agências ou empresas de seleção, recrutamento e locação de mãode-obra, como empregadoras formais que são, deparam-se com os mesmos problemas e desafios enfrentados pelos empregadores do restante da economia. Contudo, como boa parte de seus empregados estão concentrados nas atividades-meios das empresas, em setores cuja oferta de mão-de-obra é ainda abundante, uma maior flexibilidade dos direitos provavelmente facilitará a formalização e a regularização sem, entretanto, elevar o salário direto dos trabalhadores.

Embora as estatísticas oficiais ainda não tenham conseguido mensurar, os dados associativos do setor e o depoimento de importantes representantes têm indicado uma 
mudança no perfil dos empregados das agências em direção a ocupações de maior nível técnico e qualificação. Isso, aliado ao crescimento econômico, tende aos poucos melhorar as condições do trabalho, a formalização e os rendimentos dos trabalhadores das agências.

Por enquanto, elas continuam operando como um importante meio de acesso as informações "quanto às vagas, aos requerimentos necessários ao emprego e a quem possui as melhores qualificações dentre os trabalhadores para executá-lo" (Koene \& Purcell, 2004, p.19). 


\section{BiBLIOGRAFIA}

Abramo, L. W. (1999) O Resgate da Dignidade. São Paulo: Imprensa Oficial. Ed. da Unicamp.

Alexander, J. (1987) Twenty Lectures - Sociological Theory since World War II, Columbia University Press, NY.

Amuedo-Dorantes, C.; Malo, M.; Muñoz-Bullón, F. (2006) “The role of temporary help agencies in facilitating temp-to-perm transitions. In: Discussion Paper Series, n. 2177, Institute for the Study of Labor, Germany.

Andersson, F.; Holzer, H.J.; Lane, J. (2007) "Temporary help agencies and the advancement prospect of low earners". Paper preparado para a NBER Conference on Labor Market Intermediation, em 17-18 de Maio.

Antunes, R. (2007) “Dimensões da precarização estrutural do trabalho". In: Druck, G. e Franco, T. Orgs.(2007) A Perda da Razão Social do Trabalho. Terceirização e Precarização. Ed. Boitempo. São Paulo.

(1988) A Rebeldia do Trabalho. Ed. Ensaio/Unicamp. São Paulo.

Arbix, G. (2008) "Innovative firms in three emerging economies. A comparison between the Brazilian, Mexican and Argentinean industrial elite". In: Working Papers Series, Center for Latin American Studies. University of California. Berkeley. Forthcoming (formato digital disponibilizado pelo autor).

Autor, David H. (2008) "Studies of Labor Market Intermediation". Paper preparado para a NBER Conference on Labor Market Intermediation, em 17-18 de Maio.

\& Houseman (2005) "Temporary Agency Employement as a Way out of Poverty?’. In: Harvard Inequality Summer Institute, June 14-15 2006.

Bauman, Z. (2008). "Ascensão e Queda do Trabalho" in: A Sociedade Individualizada. Rio de Janeiro. Zahar, cap. I, pp 27-43.

Benner, C; Leete, L; Pastor M. (2007) Staircases or Treadmills? Labor Market Intermediaries and Economic Opportunity in Changing Economy. Russel Sage Foundation. New York.

Bernhardt, A.; Boushey, H.; Dresser, L.; Tilly, C. (2008) "An Overview of Gloves-Off Economy: Workplace Standards at the Bottom of America's Labor Market". In: The Gloves-Off Economy: Workplace Standards at the Bottom of America's Labor Market. Cornell University Press.

Bessa, V. \& Consoni, F. (2007) "Alocação de Mão-de-Obra e Mercado de Trabalho: Elementos para uma discussão sobre o mercado de intermediação no Estado de São Paulo". Artigo apresentado no V Congresso Latinoamericano de Sociologia do Trabalho, Uruguai, 18-20 de abril. 
Beynon, H. (2003) “O Sindicalismo tem futuro no século XXI?”. In: Além da Fábrica: trabalhadores, sindicatos e a nova questão social. São Paulo. Ed. Boitempo.

; Grimshaw, D.; Rubery, J.; e Ward, K.(2002) Managing Employment Change: The New Realities of Work. Oxford: Oxford University Press.

Bicev. J. (2005) “A constituição do setor de mão-de-obra temporária na Região Metropolitana de São Paulo. In: N. A. Guimarães (org.) À Procura de Trabalho. Instituições de Intermediação e redes sociais na saída do desemprego. São Paulo numa perspectiva comparada. Relatório final do Projeto CNPq - Aux. 481268/2004-9, São Paulo, CEM/DS, julho de 2007, cap. 4, pp. 131-146.

(2007) "Os trabalhadores subcontratados da Região Metropolitana de São Paulo”. Relatório final de iniciação científica, entregue a Pró-Reitoria de Pesquisa da Universidade de São Paulo em agosto de 2007.

Boito Jr, A. (1991) O Sindicalismo de Estado no Brasil. São Paulo: Hucitec/Ed. da Unicamp.

Böheim, René \& Cardoso, Ana R. (2007) “Temporary Help Services Employment in Portugal, 1995-2000”. Paper preparado para a NBER Conference on Labor Market Intermediation, em 17-18 de Maio.

Braga, R. (2006) "Uma Sociologia da Condição Proletária Contemporânea" in Tempo Social, revista de sociologia da USP, vol. 18, n.1. São Paulo.

Braverman, H. (1987) Trabalho e Capital Monopolista. Ed. Guanabara: Rio de Janeiro. Caps. 4, 5 e 6. pp 82-132.

Bresser-Pereira, L. C. (1990) "Da inflação à hiperinflação: uma abordagem estruturalista". In: Rego, J. M. (org.) Inflação e Hiperinflação - Interpretações e Retórica, São Paulo: Bienal, 1990. Pp. 7-28.

Camargo, J. M. (1996) "Flexibilidade e Produtividade no mercado de trabalho brasileiro", in: J. M. Camargo (org.) Flexibilidade do Mercado de Trabalho no Brasil. Rio, Fundação Getulio Vargas Editora, pp. 11-46.

Carelli, R. (2007) "Terceirização e Direitos Trabalhistas no Brasil”. In: Druck, G. e Franco, T. Orgs.(2007) A Perda da Razão Social do Trabalho. Terceirização e Precarização. Ed. Boitempo. São Paulo.

Cardoso, A. e Lage, T. (2005) "A inspeção do trabalho no Brasil”. In: DADOS -Revista de Ciências Sociais, Rio de Janeiro, vol. 48, n. 3, pp. 451-490.

Chesnais, F. (1996) A Mundialização do Capital. Ed. Xamã.

Coase, R. H. (1937) “The Nature of Firm”. In Economica, New Series, Vol. 4, No. 16 (November), pp. 386-405.

Colli, J. (2000) A Trama da Terceirização. Campinas, São Paulo. Ed. Unicamp. 
Consoni, F. (2009) "A profissionalização do segmento de intermediação de mão-deobra e a sofisticação dos seus serviços: das funções não-especializadas à alta qualificação". Comunicação apresentada ao Seminário de Orientação coordenado pela Profa. Dra. Nadya Araujo Guimarães, PPGS/USP, São Paulo, junho de 2009.

Coriat, B. (1992) El Taller y el Robot. Ensayos sobre el fordismo y la producción en masa en la era de la electrónica. Ed. Siglo Veintiuno.

Dau, D. M.; Rodrigues, I. J.; Conceição, J. J. Orgs. (2009) Terceirização no Brasil. Do discurso da inovação à precarização do trabalho (atualização do debate $e$ perspectivas). São Paulo. Ed. Annablume.

Druck, G. e Thébaud-Mony, A. (2007) "Terceirização: a erosão dos direitos dos trabalhadores na França e no Brasil". In: Druck, G. e Franco, T. Orgs.(2007) A Perda da Razão Social do Trabalho. Terceirização e Precarização. Ed. Boitempo. São Paulo.

e Franco, T. Orgs.(2007) A Perda da Razão Social do Trabalho. Terceirização e Precarização. Ed. Boitempo. São Paulo.

Dupas, G. (1999) "As cadeias produtivas globais e a geração de empregos", in Economia Global e Exclusão Social. Pobreza, emprego, estado e o futuro do capitalismo. Ed. Paz e Terra, São Paulo. Pp. 67-86.

Dürkheim, E. (2004) O Suicídio: estudo de Sociologia. $2^{\mathrm{a}}$ edição. Ed. Martins Fontes. São Paulo, Setembro.

(2007) As Regras do Método Sociológico. $3^{\mathrm{a} e d i c ̧ a ̃ o . ~ E d . ~ M a r t i n s ~ F o n t e s . ~}$

São Paulo.

(2008) Da Divisão do Trabalho Social. $3^{\mathrm{a}}$ edição. Ed. Martins Fontes,

São Paulo.

Echeverría, M.(2001) "Observaciones sobre, encadenamientos productivos, mercado del trabajo, calidad, condiciones y formación laboral en la industria en Chile. In: Formación Tecnica y Profesional en America Latina. CEPAL. Santiago,Chile.

(2001a) "Empresas de empleo temporario, mercado laboral y formación para el trabajo. In: Políticas para mejorar la calidad, eficiencia y la relevancia del entrenamiento profesional em America Latina y el Caribe II. CEPAL. Santiago, Chile.

Fernandes, A. J. e Pais, C. (1990) "A economia brasileira na década de 80: conseqüências da crise da dívida externa, inflação e crise do Estado". Artigo apresentado no XVIII Encontro Nacional de Economia da ANPEC (Associação Nacional de Centros de Pós-Graduação em Economia), Brasília, 4 de dezembro de 1990.

Fligstein, N. (2001) - The Architecture of Markets. An economic sociology of twentyfirst-century capitalist societies. Princeton University Press.

Forde, C. (2001) "Temporary Arrangements: the Activities of Employment Agencies in the UK". In: Work, Employment in Society 15: 3, pp. 631-644. 
Gautié, J. (2005) "Flexibilité ou sécurité? Les termes du débat". In: Flexicurité. La protection de l' emploi en débat. Dossiê organizado por Bevort, A., Lallement, $\mathrm{M}$ e Nicole-Drancourt em Dezembro de 2006.

Georges, I. e Janequine, O. (2005). "Etnografia de uma agência privada de intermediação de mão-de-obra: um negócio familiar. Documento de Trabalho. Projeto Fapesp/CEM/CNPq "À procura de trabalho. Instituições do mercado e redes de sociabilidade”, São Paulo, dezembro.

Gorz, A. (2003). As Metamorfoses do Trabalho - Crítica à razão econômica. Annablume.

Granovetter, M. (1973) "The Strength of Weak Ties" In: American Journal of Sociology, volume 78, issue 6. The University of Chicago Press.

(1985) "Economic Action and Social Structure: The Problem of Embeddedness". In: American Journal of Sociology, volume 91, issue 3. 481-510. The University of Chicago Press.

Guimarães, Nadya A. (2004) "O Sistema de Intermediação de Empregos. Um outro olhar sobre o mercado de trabalho da região metropolitana de São Paulo". Relatório ao MTE/OIT e PMSP. São Paulo, Cebrap, Dezembro, 70 pp. Disponível em 01/08/07: http://www.fflch.usp.br/sociologia/nadya.

(2006) Empresariando o Trabalho: Os agentes econômicos da intermediação de empregos, esses ilustres desconhecidos", Comunicação à Mesa Redonda "O mundo do trabalho e o empresariado", no V Workshop "Empresas, Empresários e Sociedade: O mundo empresarial e a questão social", 2 a 5 de maio de 2006, PUCRS, Porto Alegre. Versão digital em http://www.fflch.usp.br/sociologia /nadya.

(2007) "À Procura de Trabalho: desempregado, demandante de trabalho, candidato". In Revista Latino-americana de Estudos do Trabalho. Ano 13, No. 19.

(2009a) Desemprego, uma construção social. São Paulo, Paris

e Tóquio. Belo Horizonte. Ed. Argvmentvm.

(2009b) À Procura de Trabalho: Instituições do Mercado e Redes. Belo Horizonte. Ed. Argvmentvm.

(2009c) "Trajetórias surpreendentes: os intermediadores de emprego e seus trabalhadores". In: Dau, D.; Rodrigues, I.; Conceição, J. Orgs. (2009) Terceirização no Brasil. Do discurso da inovação à precarização do trabalho. Ed. Annablume. São Paulo.

e Souza, A. P. (2007) "Emprego e heterogeneidade estrutural no Brasil. Refletindo sobre tendências recentes. Relatório de consultoria. Brasília, CEPAL, maio de 2007.

Houseman, S. N. (1997) "Temporary, part-time, and contract employment in the United States: new evidence from an employer survey". WE. Upjhon Institute Employment Research, Kalamazoo, MI. 
Ichino, A.; Mealli, F.; Nannicini, T. (2005) "Temporary work agencies in Italy: A springboard toward permanent employment? Comunicação apresentada em seminário do Instituto Universitário Europeu, realizado em Março de 2005. Florença. Itália.

Jinkings, N. (2002) Trabalho e Resistência na "Fonte Misteriosa". Os bancários no mundo da eletrônica e do dinheiro. Campinas, São Paulo. Ed. Unicamp.

Jorgenson, H. \& Riemer, H. (2000) "Permatemps: Young Temp Workers as a Permanent Second Class Employees". In: American Prospect 11 (18): 38-40.

Kalleberg, A. (2000) "Nonstandard employment relations: part-time, temporary and contract work". In: Annual Review of Sociology, Vol. 26, pp.341-365.

e Marsden, P. (2005) "Externalizing organizational activities: where and how US establishments use employment intermediaries". In: Socio-Economic Review, n 3, pp 389- 416.Oxford University Press.

Kvasnicka, M. (2008) "Does temporary help work provide a stepping stone to regular employment? In: Working Papers Series, n. 13843, National Bureau of Economic Research, Cambridge, Massachusetts.

Koene, B \& Purcell, K. (2004) "The value of relationships in a transactional labour market: constructing a market for temporary employment". Outubro.

Kunda, G. \& van Maanen, J. (1999) "Changing Scripts at Work: Managers and Professionals". In Annals of the American Academy of Political and Social Science. Vol. 561, Emotional Labor in the Service Economy (Jan. 1999), pp. 64-80.

Kuttner, R. (1996) Tudo À Venda. São Paulo. Companhia das Letras.

Lima, J. C. (2007) Ligações Perigosas: trabalho flexível e trabalho associado. São Paulo. Annablume.

Magnum, G.; Mayall, D.; Nelson, K. (1985) “The temporary help industry: a response to the dual internal labor market. In: Indust. Labor Relat. Rev. 38 (4): 599-611.

Maroni, A. (1982) A Estratégia da Recusa. São Paulo. Ed. Brasiliense.

Martins, H (1994) "Os Dilemas do Movimento Sindical em Face da Terceirização" in Martins, H. \& Ramalho, J. Orgs. (1994) Terceirização: diversidade e negociação no mundo do trabalho. Ed. Hucitec. CEDI/NETS. São Paulo.

Martinussen, J. (1997) Society, State \& Market. A guide to competing theories of development. London: Zed Books.

Mocelin, D. G. (2009) “Competitividade, inovações tecnológicas e qualidade do emprego. Estudo sobre o setor de telecomunicações no Brasil”. Artigo apresentado no XIV Congresso Brasileiro de Sociologia, Rio de Janeiro, UFRJ, julho. 
Montagner, P.; Bernardes, R. C.; Matteo, M. (1999) “A demanda por serviços: o que há de novo na economia paulista". São Paulo, São Paulo em Perspectiva, v. 13, n. 1-2, p. 139-49.

Nakano, Yoshiaki (1989) "Da inércia inflacionária à hiperinflação". In: Rego, J. M., org. (1989) A Aceleração Recente da Inflação. São Paulo: Ed. Bienal.

North, D. (1990) Institutions, Institutional Change and Economic Performance. Cambridge. Cambridge University Press.

Oliviera, F. de (2003) O Ornitorrinco: crítica a razão dualista. São Paulo. Ed. Boitempo.

Pamplona, J. B. (2002) "Estudo das Empresas Prestadoras de Serviços de Seleção, Agenciamento e Locação de Mão-de-Obra do Grande ABC Paulista". Documento preparado para a Divisão de Desenvolvimento Produtivo e Empresarial da Comissão Econômica para a América Latina e Caribe (CEPAL), São Paulo, fevereiro de 2002; disponível em: GUIMARÃES, LEITE, BENTO, SOARES (2003). Gestão Local, Empregabilidade e Eqüidade de Gênero e Raça: Um Experimento de Política Pública na Região do ABC Paulista. Relatório Final, São Paulo, FAPESP/CEBRAP/Prefeitura Municipal de Santo André/CEERT/ELAS, agosto, cap. 19. Versão digital em http://www. fflch.usp.br/sociologia/nadya.

Parsons, T. (1965) "The motivation of economic activities" in Neil Smelser (org.) Readings on Economic Sociology. Englewood Cliffs: Prentice Hall, pp.53-65.

Peck, J. \& Theodore, N. (1999) "O negócio do trabalho eventual: crescimento e reestruturação na indústria de empregos temporários em Chicago". In Revista Latinoaericana de Estudios del Trabajo, ano 5, nº 10, ALAST, São Paulo, pp135-160.

Pedro, M. (2006) “A intermediação de mão-de-obra numa grande organização: especificidades de uma empresa pioneira. Documento de Trabalho, Projeto "À procura de trabalho: Instituições do trabalho e redes de sociabilidade", São Paulo, maio, 23pp.

Pochmann, M. (2007) "SINDEEPRES 15 Anos - A superterceirização dos contratos de trabalho". Pesquisa encomendada pelo SINDEEPRES. Campinas.

Reis, M. C. e Camargo, J. M. (2007) "Desemprego dos Jovens no Brasil: Os efeitos da estabilização da inflação em um mercado de trabalho com escassez de informação". In: Revista Brasileira de Economia, v. 61, n. 4. Rio de Janeiro, FGV. Pp. 493-518.

Rivero, P. S. (2009) Trabalho: Opção ou Necessidade? Um século de informalidade no Rio de Janeiro. Ed. Argvmentvm. Belo Horizonte.

Rodrigues, I. J. (1999) “A trajetória do Novo Sindicalismo". In: Rodrigues, I. Org. (1999) O Novo Sindicalismo: vinte anos depois. Ed. Vozes. Petrópolis, pp. 73-94. 
Rodrigues, I. J. e Ramalho, J. R. Orgs. (2007) Trabalho e Sindicato em Antigos e Novos Territórios Produtivos. Comparações entre o ABC Paulista e o Sul Fluminense. Ed. Annablume. São Paulo.

(2009) "Trabalho, flexibilidade e terceirização: o caso da indústria automotiva”. In: Dau, D.; Rodrigues, I.; Conceição, J. Orgs. (2009) Terceirização no Brasil. Do discurso da inovação à precarização do trabalho. Ed. Annablume. São Paulo.

Sallum, Jr. (2000) "Globalização e desenvolvimento: a estratégia brasileira nos anos 1990. In: Novos Estudos Cebrap, n. 58, São Paulo, novembro.

Santana, M. A. (2008) "New industrial areas, old workers' solidarity". In: Work organization, Labour and Globalization. Vol.2, No. 1. pp. 95 - 103. UK.

Santos, W. G. (1979) Cidadania e Justiça: a politica social na ordem brasileira. 2. Ed. Rio: Campus. Rio de Janeiro.

SEAD-DIEESE (1995) PED Conceitos, Metodologia e Operacionalização. São Paulo.

Swedberg, R. (2005) Max Weber e a Idéia de Sociologia Econômica. Ed. UFRJ/Beca Produções Culturais. Rio de Janeiro - São Paulo.

Vieira, P.(2006) "O homem e a placa ou a placa e o homem? Os homens-placa e a procura de trabalho no Centro de São Paulo". Documento de Trabalho, Projeto "À procura de trabalho: Instituições do trabalho e redes de sociabilidade”, São Paulo, maio, 20pp.

Williamson, J. (2000) "What should the World Bank think about the Washington Consensus?" Word Bank Research Observer. Vol 15, n. 2, pp. 251-264.

Williamson, O. E. (1973) "Markets and Hierarchies: Some Elementary Considerations". In The American Economic Review, Vol. 63. No. 2, Papers and Proceedings of the Eighty-fifth Annual Meeting of the American Economic Association (May), pp. 316325. 